Journal of Law and Religion 36, no. 2 (202I): 230-254 (C) The Author(s), 202I. Published by Cambridge University Press on behalf of the Center for the Study of Law and Religion at Emory University. This is an Open Access article, distributed under the terms of the Creative Commons Attribution licence (http://creativecommons.org/licenses/by/4.o/), which permits unrestricted re-use, distribution, and reproduction in any medium, provided the original work is properly cited.

doi:I0.IOI7/jlr.202I.I6

\title{
COERCION ON HOLY DAYS IN THE MIDDLE AGES
}

\author{
J. S. KIRKLAND, PhD
}

University of Iowa

\begin{abstract}
The Middle Ages are not usually considered an era when the law was friendly to laborers. Numerous regulations in medieval England were very unfriendly to them. However, religious laws-that is, canon law-did act to protect laborers when it came to working on holy days. Examining cases in the ecclesiastical courts, this article traces discussions concerning who was to blame, from theory into practice, when masters compelled their subordinates to work on holy days. Differing ideas on how to assign blame were ultimately reflected in the ecclesiastical courts. Some courts prosecuted only masters, while others prosecuted both masters and subordinates.
\end{abstract}

KEYWORDS: holy days, masters, servants, ecclesiastical courts, medieval, canon law, labor

The villeins of Todenham were upset. Their seignorial lords, the abbots of Westminster, had refused to allow them any work remittance on holy days, even the major holy days of the year. This rather strict policy had been instituted by Abbot Richard de Kedyngton (r. I3O8-I3 I 5 ) and was continued by his successor, William de Curtlington (r. I3 I 5-I333). Despite the commands of their lord, many villeins refused to work on holy days, incurring a series of fines. Curtlington eventually relaxed this policy in I32I to allow the villeins two days' work remittance at Christmas, Easter, and Whitsun. Apparently, the villeins were unimpressed. The reeve of Todenham, Henry Melksop, refused to show gratitude and was "surly" toward Curtlington, causing the abbot to withdraw the offer. ${ }^{\text {I }}$

The dispute between the villeins of Todenham and the abbots of Westminster demonstrates how holy days could become an issue between lords and their workers. It was an issue not only for villeins on estates but also for employees working for payment; both groups were considered servants (servi) by canonists. ${ }^{2}$ Ideally, medieval masters should have allowed servants to abstain from labor

I Writ from Abbot Curtlington to the reeve of Bourton-on-the-Hill, Westminster Abbey Library, Muniment 8356; Barbara Harvey, Westminster Abbey and Its Estates in the Middle Ages (Oxford: Clarendon Press, 1977), 230-3I.

2 I use the terms "master" (dominus) and "servant" (servus) throughout this article because they are the terms used by confessors' manuals and the ecclesiastical courts. These terms referred not solely to employer/employee relationships but also to a variety of unequal economic relationships. In various contexts, they respectively referred to lords and villeins, employers and employees, heads of household and dependents, and I use these terms in a similar manner. "Masters" were those in authoritative positions over "servants" or subordinates. As the jurist Albericus de Rosate Bergomensis (c. I290-I360) noted, both villeins and paid laborers could be considered servants: "serui dicuntur stricto modo carentes libertate: sed largo modo etiam seruientes pro mercede: $\&$ famuli dicuntur etiam serui a seruiendo." Albericus de Rosate Bergomensis, Dictionarium Iuris tam Ciuilis, quam Canonici [Dictionary 
on holy days and go to church. In reality, some masters made their servants work on holy days-as the villeins of Todenham knew very well. One of the major grievances noted by Geoffrey Chaucer (ca. I343-I 400) was masters who forced their servants to work on holy days. ${ }^{3}$ Without the intervention of the ecclesiastical courts, servants would be at the mercy of their lords. Fortunately for servants, some- but not all-ecclesiastical courts did prosecute masters for ordering their subordinates to work. The disparate stances of the courts reflected the differing positions put forth by various writers. Some believed that servants had a duty to disregard the orders of their masters to work on holy days. They believed that servants who worked could be equitably punished because they chose to follow impious commands. Others believed that servants should not be punished when they worked at the behest of their lord; it was, rather, their master who was to blame. These two opposing ideas remained unsettled throughout the Middle Ages and into the early modern era. It was an important question because it had practical consequences.

This article is not merely about masters and servants, however. Rather, it is about the role of coercion in unequal relationships recognized by canon law. Servants were not the only ones who could be forced to work or miss church on holy days. Wives and children also could be coerced by a demanding husband and father. Under canon law, wives ${ }^{4}$ and children were like servantsthey were not sui iuris and thus not in complete control of their affairs, according to the law. 5 Just like servants, they owed obedience to the head of the household. This legal reality was recognized by the ecclesiastical courts. Rather than prosecuting wives or children who broke holy days, the courts prosecuted the husbands and fathers who forced them to do so. The courts seem to have folded different types of social relationships involving holy-day coercion into the same legal framework. The courts prosecuted husbands for making their wives work on holy days and fathers for making their children miss church. The unequal nature of these relationship seems to have been key: coercion was an inherent component.

In this article, I shed light upon the relationship between legal theories debated in the ivory towers of the medieval universities and the practices of the ecclesiastical courts. As the late legal historian R. C. van Caenegem noted, "imaginary speculation in imaginary cases might lead to heated disputations in the universities, but it all remained a bit unreal and theoretical. . . . We come down to earth with the ecclesiastical courts: here the canon law, full of Roman law terms and norms, was applied to everyday life." ${ }^{6}$ Law students and professors in medieval universities

of civil and canon law] (Venice, I60I), s.v. "Serui." John Trevisa (ca. I340-I402), translating Bartholomew Anglicus's De Proprietatibus Rerum (in turn citing Isidore of Seville), identified three types of servants: villeins, slaves, and servants who were hired. John Trevisa, Properties of Things: John Trevisa's Translation of Bartholomaeus Anglicus De Proprietatibus Rerum, ed. M. C. Seymour (Oxford: Clarendon Press, I975), 3 I I-I 2.

3 Geoffrey Chaucer, "The Parson's Tale," lines 66I-66, in The Works of Geoffrey Chaucer, ed. F. N. Robinson, 2nd ed. (Boston: Houghton Mifflin, I957): 228-65, at 249 ("thou shalt understonde that man suffreth foure manere of grevances in outward thynges. . . The fourthe grevance is in outrageous labour in werkes. Wherefore I seye that folk that maken hir servantz to travaillen to grevously, or out of tyme, as on haly dayes, soothly they do greet synne.”).

4 In a succinct example of medieval male misogyny, Albericus de Rosate said that "the wife ought to be submissive to the husband" (uxor debet esse subdita viro). Albericus de Rosate Bergomensis, Dictionarium Iuris tam Ciuilis, quam Canonici, s.v. "Vxor debet."

5 Charles J. Reid Jr., Power over the Body, Equality in the Family: Rights and Domestic Relations in Medieval Canon Law (Grand Rapids: Wm. B. Eerdmans, 2004), 95.

6 R. C. van Caenegem, "Law in the Medieval World," Tijdschrift voor Rechtsgeschiedenis 49, no. I (I98I): I3-46, at $\mathrm{I} 7$. 
may have had the luxury to argue multiple sides of an issue, 7 but medieval ecclesiastical judges were forced to apply these abstract concepts in reality. They had to choose which legal theory to implement in their courtrooms. The multiple positions offered by writers directly affected the practices of the ecclesiastical courts. Without a firm consensus on how to assign blame, the courts implemented the law differently.

In what follows, I first provide a brief overview of canon law's treatment of holy days and coercion, then examine the historical and legal basis for prohibiting masters from forcing their servants to labor on holy days. I then look at how confessors' manuals and other works treated the issue, focusing on subtle differences accentuated by different writers. Last, I use ecclesiastical cases from England as a case study of how these canonistic ideas were applied in one particular region of Christendom. Whether the English courts were unique in this regard is unknown. Based on my analysis of these sources, I argue that medieval writers did not agree on how to allocate blame when masters compelled their subordinates to work or miss church on holy days, and that this disagreement was reflected in the practices of the ecclesiastical courts.

\section{CANON LAW}

Most of the canons concerning holy days in the Corpus Iuris Canonici ${ }^{8}$ were prohibitions. Christians were supposed to attend their parish church on holy days (X 3.29.2). Labors, markets, and most court proceedings were banned from "evening to evening” (X 2.9.I). Certain legal actions were permitted, like manumissions ${ }^{9}$ or reconciliations for peace (X 2.9.5). Weddings were banned during certain holy periods of the year, such as Lent and Advent (X 2.9.4). Local custom was

7 A central part of a medieval university education was built on introducing students to conflicting arguments and texts. The goal was not necessarily to resolve the conflicts but to provide students with a more nuanced understanding of an issue while refining their argumentation skills. See Joseph Goering, "The Scholastic Turn (I I00-I 500): Penitential Theology and Law in the Schools," in A New History of Penance, ed. Abigail Firey (Boston: Brill, 2008), 219-38, at 219-20.

8 The Corpus Iuris Canonici ("body of canon law") was the source of law for the medieval Church. It was composed of Gratian's Decretum (mid-twelfth century), Liber Extra or Decretales Gregorii IX (I234), Liber Sextus (I298), Clementines (I $3 \mathrm{I} 7$ ), Extravagantes Johannis XXII, and Extravagantes communes. Gratian's Decretum is a legal textbook credited with inaugurating the "classical period of canon law" (ca. II40-I375). In-depth discussions can be found in the following: R. H. Helmholz, The Canon Law and Ecclesiastical Jurisdiction from 597 to the I640s (New York: Oxford University Press, 2004), I48-55; James A. Brundage, Medieval Canon Law (New York: Longman, I995), 47-49. In this article, I follow the modern citation convention used for canon law outlined in Brundage, Medieval Canon Law, 190-202. The Decretum is cited by Distinctio or Causa, and then smaller subdivisions of quaestio, capitulum, or dictum. So, "C.22 q.5 c.I" refers to Causa 22, quaestio 5, capitulum I. The Decretals is symbolized by "X" and is followed by the numbers for book, title, and chapter. So, "X 2.9.I-5" refers to book 2, title 9, chapters I through 5 . Each of the sources for canon law received a standard gloss or commentary-called the Ordinary Gloss - which achieved some degree of authority. References to the Ordinary Glosses utilize the phrase "Ordinaria Glossa ad" before including the citation to the Decretum or Decretals. I rely on the I 582 Roman printing of the Corpus Iuris Canonici because it includes the Ordinary Gloss for each source: Decretales Gregorii Papae IX Suae Integritati Vna Cvm Glossis Restitvtae (Rome: In Aedibus Populi Romani, I 582); Decretum Gratiani Emendatum et Notationibus Illvstratvm Vna Cvm Glossis (Rome: In Aedibus Populi Romani, I 582). I have tried to ensure that the text of the 1582 books align with Emil Freiburg's editions of the Corpus Iuris Canonici published I879-I88I. Digitized scans of the 1582 books can be found at UCLA Digital Library Program. Corpus Juris Canonici (1582), http://digital.library.ucla.edu/canonlaw/toc.html.

9 The canon law adopted this exception from Roman law. See Clyde Pharr, trans., The Theodosian Code and Novels and the Sirmondian Constitutions (Princeton: Princeton University Press, I952), book 2.8.I, 44. 
granted a role in shaping the universal canon law to fit communities. It could determine the duration of a given holy day and how it was celebrated ( $X$ 2.9.2). Necessity and piety could trump holy-day prohibitions, allowing the illicit to become licit (X 5.4I.4). For instance, communities that relied on fishing for their survival were allowed to fish on holy days, provided that the fishermen donated a portion of their catch to the church as alms (X 2.9.3). Overall, the canon law was fairly strict about how to properly observe holy days, yet it recognized that certain situations might require prohibited activities to be carried out.

The canon law recognized that compulsion could affect one's actions and culpability. Freely given consent was required for marriage (X 4.I.I7), conversion to Christianity (X 3.42.4), and monastic vows (X I.4O.I). In determining responsibility in the face of compulsion, the canon law took several issues into account. It differentiated between those physically forced to do something and those motivated by fear of what might happen if they did not comply (X I.40.5). Fear of consequences did not excuse mortal sins, ${ }^{O}{ }^{\mathrm{i}}$ it merely diminished guilt (X I.40.5). ${ }^{\text {II }}$ Canonists urged judges to take fear into account when issuing sentences. ${ }^{\mathrm{I2}}$ Oaths could be invalidated, at the behest of the coerced party (X I.40.6), if there was a strong and real fear to shake the resolve of a "constant man" (X I.40.4). In an attempt to define degrees of compulsion, canonists adopted the concept of the constant man from Roman jurists. The constant man was courageous and steadfast, capable of withstanding empty threats or bullying. ${ }^{13} \mathrm{He}$ would be coerced only when facing a real and serious threat. Torture or the threat of death could coerce him (X I.40.6), but so could threats of disinheritance. It was left to the judge to determine whether the criteria of "just fear" (iustus metus) was enough to shake a constant man. ${ }^{\mathrm{I}}$

Despite the legal effects of coercion, canon law was clear that evil, impious commands from superiors that contravened God's commandments had to be disobeyed. ${ }^{\mathrm{I5}}$ The Decretum spelled out this rule in multiple chapters. ${ }^{16}$ Using an excerpt from Jerome's commentary on Paul's Epistle to Titus ${ }^{\mathrm{I} 7}$ and excerpts from Ambrosius, ${ }^{\mathrm{I}}{ }^{8}$ the Decretum showed that Christians were

Io X I.40.5 ("metus attenuet culpam, quia tamen non eam prorsus excludit, quum pro nullo metu debeat quis mortale peccatum incurrere.”). Ordinaria Glossa ad X I.40.5, s.v. "Casus" ("nullo metu debet quis incurrere mortale peccatum.”).

I I Ordinaria Glossa ad X I.40.5, s.v. "attenuet" ("Hic metus attenuat peccatum . . quandoque nullo modo excusat.”).

I Panormitanus, Commentaria Primae Partis In Secundum Decretalium Librum [Commentary on the first part of the Second Book of the Decretals], I.40.5.2b (Venice: Ioannem de Gara, I 57I), fol. I96r ("Ex quo ergo ratione metus debet mitius puniri, ergo non debet incurrere poenam statute . . poenam incurrit, sed iudex in impositione $\&$ executione debet habere respectum ad metum, unde debet minuere ipsam poenam.”).

I3 Brundage, Medieval Canon Law, I66.

I 4 R. H. Helmholz, Marriage Litigation in Medieval England (New York: Cambridge University Press, I974), 9I.

I 5 R. H. Helmholz, The Spirit of Classical Canon Law (Athens: University of Georgia Press, I996), 354.

I6 Decretum Gratiani Emendatvm et Notationibvs Illvstratum Vna Cum Glossis (Rome: In Aedibus Populi Romani, I 582 ); D. 8 c. 2 ("quanto magis Deo regnatori vniuersae creaturae suae, ad ea quae iusserit, sine dubitatione seruiendum est? sicut enim in potestatibus societatis humanae maior potestas minori ad obediendum praeponitur, ita Deus omnibus.").

I7 C.I I q.3 c.92 ("Non semper malum est non obedire praecepto: cum enim Dominus iubet ea, quae sunt contraria Deo; tunc ei obediendum non est.”).

I 8 C.I I q.3 c.93 ("Si dominus ea iubet, quae non sunt aduersa scripturis sanctis; subijciatur seruus domino. Si uero contraria praecipit ; magis obediat spiritus, quam corporis domino. Si bonum est, quod praecipit Imperator, \& praeses ; iubentis obsequere voluntati: si vero malum; resonde ei illud de actibus Apostolorum [Obedire oportet Deo magis, quam hominibus.] Hoc ipsum \& de seruis intelligamus apud dominos, \& de vxoribus apud viros, $\&$ de filijs apud parentes: quod in illis tantum debeant dominis, viris, parentibus esse subiecti, quae contra Dei mandata non veniunt.”). 
obliged to disobey commands that were contrary to God's word, even if the commands originated from a bishop or judge. The Ordinary Gloss of the Decretum said that in cases of evil commands, obedience was owed "to the Lord of heaven rather than the earthly lord." 19

Canon law did not explicitly discuss the issue of masters forcing their servants to work on holy days. Judges in the ecclesiastical courts were left to their own devices when faced with such cases. They had to answer several important questions when dealing with cases involving coercion on holy days. Did the master coerce the servant? Did the servant have an overriding imperative to disregard the master's order? Did the servant face a "just fear"? If so, how should blame be allocated? Was the master guilty of nonobservance? Were both the master and servant guilty of nonobservance? The answers to these questions would dictate how the law was implemented.

\section{THE HISTORICAL BASIS}

The Corpus Iuris Canonici may not have specifically addressed the issue of masters who forced their servants to work on holy days, but other texts did. Abstention from labor on holy days was enjoined by the Bible. The Third Commandment was directed primarily to the (male) heads of households. Exodus mandated that, regarding the Sabbath, "thou shalt do no work on it, thou nor thy son, nor thy daughter, nor thy manservant, nor thy maidservant, nor thy beast, nor the stranger that is within thy gates." 20 Deuteronomy reiterates the main points, adding "that thy manservant and thy maidservant may rest, even as thyself." ${ }^{2 I}$ The head of the household was responsible for the actions of his familia: wife, children, servants, animals, and guests. The master was, by definition, in a position of power over his servants. His orders had real weight.

As was true in ancient Israel, so in medieval Europe: the commandment attempted to regulate some aspect of relations between master and servant. In early medieval Europe, the version of the commandment in Deuteronomy seems to have been more influential than the version in Exodus. $^{22}$ This had ramifications, because Deuteronomy made the Sabbath a memorial to the Israelites' time of slavery in Egypt, while Exodus made it a memorial to Yahweh's rest on the seventh day. The aspect of rest from servile labor on the Sabbath was further emphasized

I9 Glossa ordinaria ad C.I I q.3 c.97, s.v. "Qui resistit" ("Dicit hic Aug. quia si aliquis non obedit potestati in bonis, Deo resistit. Si vero potestas malum iubeat, potius est obediendum domino caeli, quam domino terreno.”). Glossa ordinaria ad C.I I q.3 c.93, s.v. "Si dominus" ("Dicitur hic quod si dominus praecipiat ea quae sunt, ei est obiendum; si vero mala praecipiat, Deo coeli potius quam terreno est obediendum.”).

20 Exodus 20:8-I I ("Remember that thou keep holy the sabbath day. Six days shalt thou labour, and shalt do all thy works. But on the seventh day is the sabbath of the Lord thy God: thou shalt do no work on it, thou nor thy son, nor thy daughter, nor thy manservant, nor thy maidservant, nor thy beast, nor the stranger that is within thy gates. For in six days the Lord made heaven and earth, and the sea, and all things that are in them, and rested on the seventh day: therefore the Lord blessed the seventh day, and sanctified it."). All biblical quotations are from the Douay-Rheims translation.

2 I Deuteronomy 5:I2-I 5 ("Observe the day of the sabbath, to sanctify it, as the Lord thy God hath commanded thee. Six days shalt thou labour, and shalt do all thy works. The seventh is the day of the sabbath, that is, the rest of the Lord thy God. Thou shalt not do any work therein, thou nor thy son nor thy daughter, nor thy manservant nor thy maidservant, nor thy ox, nor thy ass, nor any of thy beasts, nor the stranger that is within thy gates: that thy manservant and thy maidservant may rest, even as thyself. Remember that thou also didst serve in Egypt, and the Lord thy God brought thee out from thence with a strong hand, and a stretched out arm. Therefore hath he commanded thee that thou shouldst observe the sabbath day.").

22 Stefan Jurasinski, The Old English Penitentials and Anglo-Saxon Law (New York: Cambridge University Press, 2OI 5), IOI-O2. 
when Leviticus 23:7 was used as a guide on how to sanctify the day. That verse orders that "The first day shall be most solemn unto you, and holy: you shall do no servile work therein." ${ }_{23}$ For Christians, then, the Third Commandment was closely associated with servants and the abstention from servile work. ${ }^{24}$

Roman law also prohibited servile work on holy days ${ }^{25}$ and made the head of the household (the paterfamilias) legally responsible for all his dependents, but it did not directly address whether masters were responsible for making their servants work on holy days. Laws from the Early Middle Ages took differing positions on whether masters were to blame when they forced their servants to work on holy days. Most of these laws assumed that masters would permit their slaves or servants some freedom on those days. The Visigothic Code (ca. 640s) ordered that slaves who worked on holy days should have their head shaved and should receive a hundred lashes. Masters "who permit them to labor" were to pay a hundred solidi to the king. ${ }^{26}$ Sometimes nothing was said about the master. The Laws of the Salian Franks (ca. 500) mandated that a slave who performed servile work on Sunday pay three solidi or be whipped. ${ }^{27}$ The laws of the Alamans (ca. 717-719) ordered that slaves who worked on Sunday be beaten with sticks. ${ }^{28}$ The Bavarian laws (ca. 744-748) punished freemen and slaves who worked on Sundays, but did not address masters. ${ }^{29}$

Even Old English laws fluctuated. $3^{\circ}$ The first extant law code from Britain, issued by King Ine of Wessex (r. 688-726), mandated that slaves who worked at the behest of their masters on Sunday were to be freed, while the master was forced to pay a fine of thirty shillings. ${ }^{35}$ The law code of Wihtred of Kent (r. 690-725) prescribed punishment only for servants. ${ }^{32}$ Wihtred's law seems to have assumed that masters would desist from ordering their servants to work, but it is not clear

23 Leviticus 23:7.

24 R. J. Bauckham, "Sabbath and Sunday in the Medieval Church in the West," in From Sabbath to Lord's Day: A Biblical, Historical, and Theological Investigation, ed. D. A. Carson (Grand Rapids: Zondervan, I982), 299-309, at 305-06; L. L. McReavy, "Servile Work: The Evolution of the Present Sunday Law," Clergy Review, no. 9 (I935): 269-84.

25 Cicero, “The Laws," Book 2.19-20, in Niall Rudd, trans., "The Republic” and "The Laws” (New York: Oxford University Press, I998): 95-165, at I28-29. See also Adolf Berger, Encyclopedic Dictionary of Roman Law, (Philadelphia: American Philosophical Society, I953), s.v. "Feriae (dies festi)," 333-8I0, at 470.

26 S. P. Scott, trans., The Visigothic Code (Forum Judicum) (Boston: Boston Book Company, I910), 387.

27 Theodore John Rivers, trans., Laws of the Salian and Ripuarian Franks (New York: AMS Press, I986), I47.

28 Theodore John Rivers, trans., Laws of the Alamans and Bavarians (Philadelphia: University of Pennsylvania Press, I977), c. 38 , at 79 .

29 Rivers, Laws of the Alamans and Bavarians, c. 3 a, at 137.

30 For discussions surrounding these laws, see Dorothy Haines, Sunday Observance and the Sunday Letter in Anglo-Saxon England (Cambridge: D. S. Brewer, 2010), I9-2I; Jurasinski, Old English Penitentials, 99-I10; Tom Lambert, Law and Order in Anglo-Saxon England (New York: Oxford University Press, 2017), 87, 95, 106. Note that the Old English laws are cited in the citation style preferred by legal historians in the field. It is based on the citation style established by Felix Liebermann in Die Gesetze der Angelsachsen [The laws of the Anglo-Saxons], 3 vols. (Halle: Max Niemeyer, I903-I9I6). To assist those less familiar with the intricacies of Old English legal history, I also cite the source in which a translation can be found.

3 I Ine, 3. $\$ \mathrm{I}-2$; “The Laws of Ine," in Laws of the Earliest English Kings, ed. and trans. F. L. Attenborough (Cambridge: Cambridge University Press, I922), 36-6I, at 36 ("If a slave works on Sunday by his lord's command, he shall become free, and the lord shall pay a fine of 30 shillings. If, however, the slave works without the cognizance of his master, he shall undergo the lash or pay the fine in lieu thereof. If, however, a freeman works on that day, except by his lord's command, he shall be reduced to slavery, or [pay a fine of] 60 shillings. A priest shall pay a double fine.").

32 Wihtred 8. $\int \mathrm{I}-2$, “The Laws of Wihtred," in The Beginnings of English Law, ed. Lisi Oliver (Toronto: Toronto University Press, 2002), I 52-63, at I 57 ("If a servant performs [work] on his own counsel on that day, let him pay 6 towards his lord or his hide. If, however, a freeman [works] in that forbidden time, let him be liable for 
who was to blame when masters made their servants work. This ambiguity was a recurring feature in many sabbatarian laws throughout the Middle Ages.

Several English law codes avoided the master-servant issue. The law codes of Alfred, Æthelstan (r. 924-939), Edgar (r. 959-975), and Æthelred II, the Unready (r. 978-IOI6), dealt with holy days but did not discuss masters who forced their servants to work. 33 There appears to have been no further legislation on the issue until Archbishop Wulfstan of York (r. IO02-IO23) attempted to reform the English church. He resorted to forging a series of laws called "The Laws of Edward and Guthrum." 34 Wulfstan included a law that said, "If a slave is compelled to work by his lord during a church festival, he [the lord] shall pay labslit [a fine] within the Danelagh, and a fine in an English district." 35 As with Ine's law, Wulfstan's law made masters wholly responsible if they required their slaves to work on a holy day. The law clearly sought to ensure that masters would not profane holy days by forcing their inferiors to work, even if the punishment was not as severe as in Ine's law, which freed the slave. ${ }^{36}$ Just like Ine's law, Wulfstan's sought to dissuade masters with a monetary penalty.

Wulfstan was also behind the creation of laws under Cnut (r. Ior 8-I035). These included a law that said, "If a slave works [during a church festival], he shall undergo the lash or pay the fine in lieu thereof, according to the nature of the offence. If a lord compels his slave to work during a church festival, he shall lose the slave, who shall henceforth obtain the rights of a freeman, and the lord shall pay lahslit in a Danish district and a fine in an English one, according to the nature of the offence, or else he shall clear himself." 37 Cnut's law was similar in many regards to Ine's in that it freed the slave and assigned a monetary penalty to the master.

The Norwegian Frostathing law dealt with the master-servant issue. The Frostathing law, which derives its name from the court at Frostating, was created in the Trondelaw region of Norway around I260. It was not as clear as Cnut's law, but it seems to have made the master responsible. It said that the fine for a bondman who worked on a holy day was six oras. If he worked without the command of his master, the master was to pay three oras or have the bondman flogged. ${ }^{8}$

healsfang, and the man who detects that, he shall own half that fine and/or that work." Oliver's translation and interpolations.).

33 Alfred, 43; "The Laws of Alfred," in Laws of the Earliest English Kings, 62-94, at 84-87; II Æthelstan, 24.I; IV Æthelstan, 2; VI Æthelstan, Io; II Edgar, 5; VI Æthelred, 22-25, 43 in Die Gesetze der Angelsachsen, ed. F. Liebermann, 3 vols. (Halle: Max Niemeyer, I903): I:I64, I7I, I8I-82, I98, 252-54, 258.

34 Dorothy Whitelock, "Wulfstan and the So-Called Laws of Edward and Guthrum," English Historical Review 56, no. 22I (I94I): I-2I.

35 Edward and Guthrum, 7.\$2; "The Laws of Edward and Guthrum," in Laws of the Earliest English Kings, IO2I IO, at I07 ("If a freeman works during a church festival, he shall be reduced to slavery, or pay a fine or lahslit. A slave shall undergo the lash or pay the fine in lieu thereof. If a slave is compelled to work by his lord during a church festival, he [the lord] shall pay lahslit within the Danelagh, and a fine in an English district.”).

36 For the argument that Wulfstan saw slaves as humans with rights, see David A. E. Pelteret, Slavery in Early Mediaeval England: From the Reign of Alfred Until the Twelfth Century (Woodbridge: Boydell Press, 1995), 9I-IOI.

37 II Cnut, 45; “The Laws of Canute," in A. J. Robertson, trans., The Laws of the Kings of England from Edmund to Henry I (Cambridge: Cambridge University Press, I925), I35-219, at 199.

38 "The Older Law of the Frostathing," in The Earliest Norwegian Laws: Being the Gulathing Law and the Frostathing Law, trans. Laurence Marcellus Larson (New York: Columbia University Press, 1935), c. 28, at 237 ("If a man is found at work on any one of those days that are counted holy . . . he shall pay six oras. . . . [The fine is] the same for a bondman who works on his master's orders; but if he works on his own volition, his master shall pay three oras or have the thrall flogged."). 
The law implied that slaves had some agency on holy days, but it still held masters responsible. 39 If the master chose to have his bondman flogged, he still would likely lose some production from his bondman, thereby impacting the master's wealth.

Theological and pastoral texts produced in the High and Late Middle Ages weighed in on the issue of holy days. Two questions needed to be answered: Who was responsible when masters ordered their servants to work on holy days? And could servants disobey their master's demands to work on a holy day? It is unclear whether the early medieval holy-day laws provoked this debate, or whether it was a result of reflections on holy days among university professors and students. Regardless, the debate did not result in lengthy treatises about feria, or holy days. Most of the debate that survives in these documents is limited to a few lines. However, the issue had great importance. At its heart lay the question of how to assign blame-an especially important issue for confessors and ecclesiastical courts who had to deal with the issue "on the ground."

Discourse concerning holy days followed the trajectory of debate over just wars. Theologians and canonists accepted that some wars were just while others were unjust. One of the issues they discussed was whether vassals were obliged to obey their lords in unjust wars. The Decretum was unclear. It absolved warriors of all blame when they followed evil commands, while placing all the blame on the prince, but it did not state whether vassals could refuse their lords. $4^{\circ}$ Many writers, including Johannes Teutonicus (ca. II7O-I245) in the Ordinary Gloss of the Decretum, argued that vassals were not bound to follow the commands of their lords waging unjust wars, because obedience would lead to sinful acts.4r Robert of Courçon (ca. I I 58-I 2I9) said that soldiers were not bound to obey their earthly lords in unjust wars. ${ }^{42}$ Odofredus (d. I265) argued that a vassal was not bound to fight in a clearly unjust war or when obedience to his lord would result in sin. 43 These ideas concerning obedience in unjust wars remained influential in the fourteenth century. Ranulph Higden (ca. I280-I364) agreed that a soldier should not obey his lord when he knew the war was unjust. In essence, this constituted a duty to refuse unjust orders. Authorities were absolved of guilt only if they knew the war to be just. 44

It was an important step when ideas concerning obedience and just wars were applied to holy days. Holy days occupied a far larger place in everyday life than just wars, which occurred far less frequently than holy days. Just wars also omitted noncombatants like women, children, the elderly, the disabled, and the clergy, while holy days encompassed all groups of society. There were real implications for everyday relations between masters and servants over the issue of obedience on holy days.

Hagiographical tales occasionally dealt with the issue. They demonstrate that there was a long tradition that attributed wrongdoing to the servant, even when the servant had been ordered to work. Gregory of Tours (ca. 538-594) told a couple of tales about slaves who were punished

39 Ruth Mazo Karras, Slavery and Society in Medieval Scandinavia (New Haven: Yale University Press, I988), I Io-I I, 233. For Swedish provincial laws that regulated holy day observance, see Mia Korpiola, "On Ecclesiastical Jurisdiction and the Reception of Canon Law in the Swedish Provincial Laws," in How Nordic Are the Nordic Medieval Laws? Proceedings from the First Carlsberg Conference on Medieval Legal History Second Edition 20II, ed. Per Andersen, Ditlev Tamm, and Helle Vogt (Copenhagen: DJØF, 20II), 207-34, at 2I 2, 214 , 22 I.

40 C.23 q.I c. 4 ; C.23 q.5 c.25.

4I Frederick H. Russell, The Just War in the Middle Ages (New York: Cambridge University Press, I975), I49; Glossa ordinaria ad C.22 q.5 c.I8, s.v. "honestum”; Glossa ordinaria ad C.22 q.5 c.I, s.v. "et milites.”

42 Russell, Just War, 225.

43 Russell, 47-48.

44 Ranulph Higden, Speculum Curatorum: A Mirror for Curates, book I, The Commandments, ed. and trans. Eugene Crook and Margaret Jennings (Walpole: Peeters, 201 2), 262-63. 
for working on holy days.45 One slave in Tours, a man named Ursulf, was "ordered by his master" to walk around a field during Easter week. On discovering a breach in the fence, he closed it. $\mathrm{He}$ was subsequently blinded by divine vengeance and healed only when he made a pilgrimage to the tomb of Saint Martin, the bishop of Tours. ${ }^{6}$ When another slave in Tours repaired a fence on Sunday, the wooden mallet he was using began sticking to his hand. After letting go of the mallet, his hand painfully contracted, causing his nails to dig into his palm. His hand remained in this condition for four years, healing only after he prayed at the basilica of Saint Martin of Tours. 47

The hagiographic tradition around labor on holy days continued into the High Middle Ages. A hagiographical tale in the Liber Eliensis (ca. twelfth century) portrayed one servant's divine punishment for working on a holy day. A priest staying at the monastery of Ely "compelled" his servant girl to gather vegetables from the garden before the third hour on a Sunday. The girl took a huge stake to gather the vegetables. Suddenly, her hand stuck to the wood she was holding. The stake was so firmly stuck onto her hand that "no one of the human race" was able to pull it off. The stake caused the girl great pain and remained fastened to her hand for five years. Not until the girl was taken to church, and prayers to God and Saint Æthelthryth were said, did the girl's hand open and allow the stake to fall to the ground. The flesh on her hand had rotted away; only the bone remained. $4^{8}$ This story had multiple moral components. The author attempted to prove the holiness of Saint Æthelthryth, but he simultaneously demonstrated his opinion on holyday offenses. The entire guilt and punishment for working on the holy day fell on the servant, even though she had been compelled. Apparently, the author of the tale did not believe that compulsion was a satisfactory excuse to God. The servant was punished, not the master. The author seems to imply that the servant girl should have refused her master's commands; her life might have been better off if she had.

A century later, in his Treatise on the Miracles of Saint Francis (ca. I250), the Franciscan friar Thomas of Celano (ca. II $85-\mathrm{I} 265$ ) blamed servants for working on holy days. The story was

45 Gregory actually told three tales involving slaves working on holy days. However, in one tale he specifically noted that the slave woman worked "in secret" and "all by herself." It seems that her master did not compel or even know that she was working on a holy day. Gregory of Tours, "The Miracles of Bishop Martin," in Lives and Miracles, ed. and trans. Giselle de Nie (Cambridge, MA: Harvard University Press, 20I 5), book 2.58, at 652-55.

46 Gregory of Tours, "The Miracles of Bishop Martin," book 2.I3, at 556-59.

47 Gregory of Tours, book 2.29, at 7IO-II.

48 Janet Fairweather, trans., Liber Eliensis: A History of the Isle of Ely from the Seventh Century to the Twelfth, Compiled by a Monk of Ely in the Twelfth Century (Woodbridge: Boydell Press, 2005), book I.48, at 79-80 ("there was a certain priest staying in the monastery who compelled his servant-girl to gather vegetables in the garden before the third hour on a Sunday. She had seized a huge stake in order to fulfill her master's order, when her hand became firmly stuck to the piece of wood which she was eagerly clutching and with which she was bent on uprooting the herbs illicitly. So firmly was it stuck that no one of the human race had been able by any endeavor to pull the stake out of the woman's hand. As she was tormented by a great agony they cut the stake on either side of her hand, being unable to give the wretched woman any other help, and she remained in this state for five years. When, with the revolving of Heaven's axis, those years were complete, it happened that we who were to help her met one day at the house of the aforementioned priest. When we saw her being tormented beyond all measure, we were very grieved that a creature of God should be perishing in this way, and said with united voice to the priest with whom we were sharing a meal: 'Before we take our food, let us take this poor woman to that church of yours, humbly beseeching the Maker of all created things to deign to have mercy upon her through the glorious intervention of the holy virgin Æthelthryth.'. . They entered the basilica and as soon as they had made their request to the Lord, the servant's hand opened up and out sprang the wood, which was now adhering to the joints of the bones, as the flesh was wasted away! And so, the woman received divine healing, and the fathering of clerics returned for the shared meal, giving thanks and praise to Christ the Savior.”). 
propaganda meant to confirm the sanctity of Francis and the validity of his feast day. It also suggested that servants should observe holy days despite the orders of their masters. Thomas wrote that in Le Mans, a noblewoman forced her female servant to do servile work on the feast of Saint Francis. The servant initially refused. "Human fear, however, prevailed over fear of God, and the girl did as she was told, even if unwillingly." As soon as she began to use a spindle, her hands froze, and her fingers burned. She ran to the Franciscan friars and told them of her impious deeds, begging forgiveness. The brothers marched to the church and prayed to Saint Francis that he would show mercy and heal the girl. He did; her hands were healed with only a trace of the burn remaining. 49 The story implies that the duty of servants to observe holy days superseded the obedience they owed their masters. The girl should have observed the feast despite the commands (and potential beatings) of her mistress. The girl was punished by the divine not when she initially refused the commands of her mistress, but only when she began to work.

Whether or not the story is true, it shows that in the thirteenth century, some believed that servants had the duty to observe holy days and could refuse the demands of their masters. Thomas was writing propaganda, which meant that the inclusion and exclusion of sources was a deliberate choice. He could have left the story out. He had plenty of stories that showed Saint Francis's feast was a valid holy day. But he included the story, which had a moral component, seemingly for servants: it is better to observe holy days than to obey impious orders. The noblewoman was not punished, even though, as is demonstrated below, confessors' manuals maintained that masters are guilty of sin for making their servants work.

Other hagiographical tales and exempla place the blame on masters. A story in British Library MS Cleopatra D. VIII tells how a man was killed after forcing his servant to cut a tree branch on Sunday. The branch the servant was ordered to cut fell on the master's head, killing him. ${ }^{\circ \circ}$ The Life of Saint Kenelm places the blame on masters. A priest in Pailton directed that the feast of the saint should be celebrated by a cessation of work. The lady who presided over the village refused to allow villagers to observe the holy day. As a result, her eyes fell out of her head. Furthermore, her oxen, which were yoked to carts, shook off their yokes and ran off, never to be found. The story clearly attempts to show that masters were in danger when they refused to let their servants observe holy days, specifically the feast of Saint Kenelm. ${ }^{5 \text { I }}$

49 Thomas of Celano, "Treatise on the Miracles of Saint Francis," in Francis of Assisi: Early Documents, vol. 2, ed. [and trans.] Regis J. Armstrong, J. A. Wayne Hellmann, and William J. Short (New York: New City Press, 2000), 395-468, at 442 ("A noble woman in the city of Le Mans had a lowly servant girl whom she forced to do servile work on the feast of Saint Francis. But the girl was of nobler mind and refused, out of reverence for the feast. Human fear, however, prevailed over fear of God, and the girl did as she was told, even if unwillingly. She put her hand to the distaff, her fingers plied the spindle. But immediately her hands stiffened with pain and her fingers burned unbearably. The punishment revealed the fault as the sharpness of the pain made silence impossible. The girl hurried to the sons of Saint Francis, revealed her offense, showed her punishment, and asked forgiveness. So the brothers marched in procession to the church and begged Saint Francis's mercy for the girl's health. As the sons begged their father she was healed, though a trace of the burning remained on her hands.").

50 J. A. Herbert, ed., Catalogue of Romances in the Department of Manuscripts in the British Museum, vol. 3 (London: British Museum, I9I0), 640; Frederic C. Tubach, Index Exemplorum: A Handbook of Medieval Religious Tales (Helsinki: Suomalainen Tiedeakatemia Akademia Scientiarum Fennica, 1969), 317.

5 I Rosalind Love, trans., "Vita et Miracula S. Kenelmi," in Three Eleventh-Centrury Anglo-Latin Saints' Lives: Vita S. Birini, Vita et Miracula S. Kenelmi, Vita S. Rumwoldi (Oxford: Clarendon Press, 1996), 49-90, at 77 ("At that time the priest of Pailton, as was the custom, directed that the feast of St Kenelm should be celebrated by a break from work. When the lady who presided over the village heard this, as she reclined at dinner on that very feast-day, she refuted it with arrogant pride, hurled impatient words at the saint, and commanded with haughty contempt that no work should be interrupted. 'Just because of Kenelm,' she said, 'I don't know why we should lose a day's 
A Dominican tale from the vita of Saint Peter of Verona (I 206-I 252) also includes an example of a servant forced to work on the saint's feast day. A "heretical" master ordered his servant boy to burn down the woods of Milan. The boy feared his lord and obeyed his command. When the boy began to chop up an oak tree to start the fire, blood poured forth from the tree. The boy subsequently told everyone what had happened, and his lord was converted by the miracle. ${ }^{52}$ The vita notes that the boy had gone to do his task because he feared his lord. This was an important inclusion, because discourses on whether servants sinned by working on holy days centered on whether they worked out of "just fear" of their lords. The author of Saint Peter of Verona's hagiography seems to have been familiar with the concept of "just fear" and used his knowledge to explain why the pious boy followed the impious commands of his lord. The story also helps explain why the boy did not receive divine punishment. The boy was not guilty of sinning, because he worked out of just fear. His heretical lord was responsible.

There were English versions of this exempla. A thirteenth-century exempla collection compiled by an English friar describes a similar miracle told by a Yorkshireman, with a few additions. This time, the Cistercian lay brothers of Kilnsey, in Yorkshire, had sent a young man and one of the servants to cut down a tree on Sunday. When the man began cutting the tree, blood poured forth. $\mathrm{He}$ was blinded and fell down. The servant tried to pick up the ax, but failed. Instead, he made the sign of the cross on the blinded man's eyes, allowing him to regain his sight. Undismayed, the man continued to cut down the tree. This time, a voice ordered him three times to leave. After the third time, the voice said, "Cursed be he that sent you here!" A few days later the man was killed by either the lay brother who had sent him or another lay brother-the scribe was unsure of which. The scribe also mentioned that he did not know what happened to the lay-brother, or whether he even faced trial. 53

profit.' Scarcely had she spoken when both her eyes shot on to the table. . . . Now indeed in late repentance she calls on St. Kenelm with grief and wailing, and begged that his feast day be celebrated with all reverence. Rightly she who despised the one special day of God's beloved, ceased to care about all days. Furthermore, her oxen, which were that day yoked up to carts, shook off all their reigns and yokes and scattered so that they could not afterwards be found.").

52 Donald Prudlo, trans., "Life and Cult of Peter the Martyr," in The Martyred Inquisitor: The Life and Cult of Peter of Verona (†I252) (Burlington: Ashgate, 2008), Appendix B, pp. 203-262, at 233 ("After Blessed Peter Martyr was canonized and his feast had been solemnly celebrated in Milan, a certain believer of the heretics sent his servant boy into the woods in order to burn them down. The boy, fearing his lord, went to do the task, asking the Lord Jesus Christ that for the honor of the Saint to whom his lord wished to do injury, He would deign to accomplish some miracle. When he was about to burn the oak, having taken up the axe, from the first cut blood began to flow copiously, so that the iron and the handle and his hands and a great quantity of earth was reddened with blood. Then crying out, he immediately returned, and faithfully related what had taken place. Many ran back with the lord, and truly saw the miracle of Blessed Peter Martyr and had great devotion. The incredulous one was converted to the veneration of the saint and to the Catholic faith.").

53 David Jones, trans., "Selected Exempla from the Cambridge Dominican Collection," in Friars' Tales: Thirteenth-Century Exempla from the British Isles (New York: Manchester University Press, 20II), no. 86, pp. I 54-88, at I63-64 ("On a Sunday, perhaps around the time for mass, they [the Cistercian lay-brothers] sent a young man and one of the other servants into the wood to cut down a tree for one of the monks. When the young man struck the tree, blood poured out. The young man saw this and did not thank God for so great a miracle; but he fell down and was struck blind. The servant wanted to pick up his axe but he could no longer do so. What a great miracle! The servant saw this and made the sign of the Cross on the eyes of the blinded man and his sight was restored. Realising that he had regained his sight, he immediately got up and again began to cut the tree, which still continued to bleed. ... [A] voice said in English, 'Leave, leave, leave!' The unfortunate one replied, 'You will not scare me like this!' Again the voice repeated the same words but he replied in the same way as before. The voice came for a third time and repeated the words and added, 'Cursed be he that sent you 
This tale demonstrates from an English point of view who was responsible when servants were ordered to work on holy days, although the tale seemingly confuses different stories and ideas. The young man sent with the servant could be considered a servant himself, since he was ordered to work on Sunday. The friar was not hung up on this fact, but he seems to have questioned some of the events of the story. The story suggests that the man ordered to cut down the tree was guilty of sin. He was, after all, blinded and eventually murdered. However, the story also suggests that the one who ordered him to work - the lay brother(s) - was responsible. The tree specifically cursed the one who gave the orders. The storytelling friar seems puzzled by this as well. He and his intended audience are curious about what became of the lay brother. Their curiosity-as well as part of the tale-assumes that some of the sin lay with the lay brother(s) for ordering a tree to be cut down on a Sunday. The implicit assumption is that the one who gave the orders and the one who carried them out both sinned, and both should be punished.

Some writers believed that servants sinned when they worked on holy days, regardless of whether their master commanded them. Humbert of Romans (ca. I I90-I 277) noted that servants rarely went to church, many under the influence of their masters. They offended the Lord of lords on account of their earthly lord. 54 Johannes Herolt (d. I468) concurred. 55 Other writers disagreed. Thomas Aquinas (I225-I 274) argued that servants could licitly do servile work on holy days when commanded by their superiors. ${ }^{56}$ Berthold of Regensburg (ca. I2IO-I272) preached that masters abused their servants when they forced them to perform unnecessary works on Sunday. 57 There were clearly differing opinions about who sinned when masters compelled their servants to work on holy days.

\section{CONFESSORS’ MANUALS}

Though multiple hagiographies imply that servants should abstain from work on holy days despite the injunctions of their masters, most of these tales are vague. Manuals for confessors-works

here!' When they left, a few days later, the lay-brother who had sent the young man to the forest or his fellow lay-brother killed the young man. I do not know what befell the lay-brother or whether he ever faced trial.").

54 Alexander Murray, "Piety and Impiety in Thirteenth-Century Italy," in Discipline and Diversity: Papers Read at the 2005 Summer Meeting and the 2006 Winter Meeting of the Ecclesiastical History Society, ed. Kate Cooper and Jeremy Gregory (Woodbridge: Boydell Press, 2007), 83-106 at 92-93; Alexander Murray, "Religion among the Poor in Thirteenth-Century France: The Testimony of Humbert of Romans," Traditio 30 (1974): 285-324, at 30I-02, 305; Humbertus de Romanis, "De eruditione praedicatorum," in Maxima Bibliotheca Veterum Patrum [The great library of the ancient fathers] vol. 25 (Lyon, 1677), cap. 77, 494B ("Notandum etiam, quod aliqui famuli propter ipsos Dominos suos male se habent ad Deum, aut eis seruiendo in peccatis, aut propter eos aliqua peccata faciendo, aut propter eos quae Dei sunt omittendo, vt ad Ecclesiam nunquam veniendo, aut festa Dei frangendo, \& similia: offendendo Dominum Dominorum, propter Dominum terram.”).

55 Johannes Herolt, "De duodecim fructibus missae," Sermo 48 in Sermones Discipvli, De Tempore, \& de Sanctis, cvm Exemplorvm Promptvario, ac Miraculis B. Virginis [Sermons of Discipulus on time and on the saints with a repository of examples and miracles of the Blessed Virgin] (Venice: Apud Haeredes Melchioris Sessae, I 584 ), I 59 ("Item sciendum, quia famule $\&$ ancille, filij $\&$ filiae tenentur Dominica die audire missam integram; $\&$ si Domini eos impedirent sine rationabili causam, vel iuberent eos laborare in die festiuo, in eos redundaret, $\&$ in hoc grauiter peccant.”).

56 Thomas Aquinas, The Catechetical Instructions of St. Thomas Aquinas, trans. Joseph B. Collins (New York: Joseph F. Wagner, 1939), 82 ("We ought to know, however, that servile work can be done on the Sabbath for four reasons. ... And the fourth reason is the authority of our superiors.").

57 John Dahmus, "Medieval German Preaching on the Ten Commandments: A Comparison of Berthold of Regensburg and John Nider," Medieval Sermon Studies, no. 44 (2000): 37-52, at 42. 
intended to provide confessors with the information needed to assign penance for $\sin ^{58}$ - discuss the issue directly. One of the main sources that engendered discussion about servants forced to work on holy days was a gloss composed around I24I by William of Rennes on Raymond of Peñafort's Summa de poenitentia et matrimonio. 59 Raymond divided his chapter on holy days and fasts into seven sections, which defined holy days, listed the major universal feasts, and discussed how they should be observed along with prohibitions. In a long commentary on Raymond's seventh section, which argues that necessary things could be done on holy days, William of Rennes asks whether it is a sin for servants to work on holy days when their masters compel them. His conclusion is that servants do not sin as long as they are induced by "just fear" (iusto metu) since this falls under the category of necessity. ${ }^{60} \mathrm{He}$ does not explicitly say whether servants can refuse to obey their master's demands on holy days, but he seems to imply it. He implies that without just fear, servants are responsible for working. If a master simply asks a servant to work without the threat of harsh consequences, then the servant is not excused: there is no just fear. William notes that servants are not excused if they choose to do the boon works they owe their lord on feasts so that they can have a regular day off-unless strong necessity compels them. He also notes that Raymond did not include any of this in his discussion. This is an important inclusion by William. When the Summa de poenitentia et matrimonio became a popular and widespread manual for confessors, William's gloss went with it. William's discussion is not very long. He placed it between a discussion on whether butchers, cupbearers (pincernae), and others commit a mortal sin by preparing victuals on holy days (no, if they have no other time to

58 Confessors' manuals were created as a result of a pastoral movement beginning in the late twelfth century that sought to bring university theology to the parish cleric. A few Englishmen who studied at Paris in the late twelfth and early thirteenth centuries created some pastoral works that were forerunners of confessors' manuals. However, it was the Dominicans who led the development of confessors' manuals. See Leonard E. Boyle, "The Inter-Conciliar Period II 79-I2I 5 and the Beginnings of Pastoral Manuals," in Miscellanea Rolando Bandinelli Papa Alessandro III [Miscellany of Roland Bandinelli, Pope Alessandro III], ed. Filippo Liotta and Roberto Tofanini (Siena: Accademia senese degli intronati, 1986), 45-56; Leonard E. Boyle, "A Study of the Works Attributed to William of Pagula with Special Reference to the Oculus Sacerdotis and Summa Summarum," (PhD diss., University of Oxford, I956), I:I92-259; Leonard E. Boyle, "Summae Confessorum," in Les genres littéraires dans les sources théologiques et philosophiques médiévales. Définition, critique et exploitation. Actes $d u$ Colloque international de Louvain-la-Neuve $25-27$ mai I98 I [Literary genres in medieval theological and philosophical sources. Definition, criticism, and exploitation. Proceedings of the International Colloquium of Louvain-la-Neuve, May 25-27, I98I] (Louvain-la-Neuve: Université catholique de Louvain, 1982), 227-37; Vincent Gillespie, "Doctrina and Predicacio: The Design and Function of Some Pastoral Manuals," Leeds Studies in English, no. II, n.s. (1980): 36-50; Judith Shaw, "The Influence of Canonical and Episcopal Reform on Popular Books of Instruction," in The Popular Literature of Medieval England, ed. Thomas J. Heffernan (Knoxville: University of Tennessee Press, 1985), 44-60; M. Michèle Mulchahey, First the Bow is Bent in Study: Dominican Education before 1350 (Toronto: Pontifical Institute of Mediaeval Studies, 1998), 216-I7, 527-52.

59 The gloss was incorrectly attributed to John of Freiburg in the 1603 edition of Summa de poenitentia et matrimonio. For a brief discussion of William of Rennes, see Pierre Michaud-Quantin, Sommes des casuistique et manuals de confession au Moyen Âge (XII-XVI siècles)[Summas of casuistry and manuals of confession in the Middle Ages (twelfth through sixteenth centuries] (Montreal: Librairie Dominicaine, I962), 40-4I.

60 William of Rennes, "Apparatus ad Summam Raymundi," in Summa sancti Raymundi de Peniafort Barcinonensis, ordinis praedicatorum, de poenitentia, et matrimonio cum glossis Ioannis de Friburgo [Summa of Saint Raymond de Peñafort of Barcelona, Order of preachers, On penance and matrimony with the Gloss of John of Freiburg] (Rome: Ioannis Tallini, I603), I.I 2.7, s.v. "Necessitate," at I I 4 ("Illi etiam, qui a dominis suis compelluntur operari in festis, si iusto metu inducti hoc faciant, videntur propter necessitem posse excusari. Qui vero, dum debent vecturam bladorum dominis suis, ea afferent diebus feriandis, vt reliquis diebus profestis possint liberius consuetis, \& proprijs vacare laboribus, non sunt excusabiles in hoc, nisi forte arcta necessitas ad hoc eos compellat.”). 
do so) and a discussion on whether scholars may transcribe their notes (yes, if they need to do so to remember them). This organization is followed by several other writers in their own texts over the next three hundred years. ${ }^{6}$

Writers throughout the thirteenth and early fourteenth centuries copied William of Rennes's ambiguous statement that servants were not guilty of working on holy days if they were compelled by their masters. Vincent of Beauvais (ca. II 90-I 264), ${ }^{62}$ John of Freiburg (d. I3 I4), ${ }^{63}$ John of Erfurt (ca. I250-I325), 64 Astesanus of Asti (d. I330), ${ }^{65}$ William of Pagula (d. I332), 66 Denis the Carthusian (I402-I47I), 67 and Angelo Carletti di Chivasso (I4II-I495) ${ }^{68}$ included William's statement in their own works, though without adding much. They all agreed that servants compelled by their masters to work on holy days were excused if they were induced by just fear; however, none of them explicitly stated whether servants had an imperative to disregard orders made on holy days.

Without a definite statement that servants could refuse the commands of their masters on holy days, people could argue that servants had to obey. The anonymous author of Dives and Pauper, a

6I Perhaps drawing on a different tradition than that of William of Rennes, the short thirteenth-century English confessional manual Animetur primo asked penitents if they had "disdained to keep the saints' holidays and feast days laid down by the church, either in his own person or through his servants and animals." It seems to have blamed masters for making their servants work on holy days, perhaps indicating that discussion about how to assign blame was not simply a discourse limited to William of Rennes and his readers. See an edition, translation, and discussion of the Animetur primo in Catherine Rider, "What to Ask in Confession: A List of Sins from Thirteenth-Century England," in Pastoral Care in Medieval England: Interdisciplinary Approaches, ed. Peter D. Clarke and Sarah James (New York: Routledge, 2020), 67-99, at 88.

62 Vincent of Beauvais, Bibliotheca Mvndi sev Specvli Maioris [Library of the world or the great mirror], vol. 2 (Speculum Doctrinale [Mirror of doctrine]) (Douai: Baltazaris Belleri, I624), 876b ("Illi etiam qui a dominis suis compelluntur operari in festis, si iusto metu inducti hoc faciunt, videntur per necessitate posse excusari. Qui vero cum debeant vecturam bladorum dominis suis, afferunt ea diebus feriandis, vt reliquis diebus profestis possint liberius consuetis \& proprijs vacare laboribus, non sunt excusabiles in hoc, nisi forte arcta necessitas ad hoc eos compellat.”).

63 John of Freiburg, Summa Confessorum [Summa of confessors] (Lyons: Jacobus Saccon, I 5 I 8), I.I 2.9, fol. 34r ("Illi autem quo a dominis suis compelluntur operari in diebus festis si iusto metu inducti hoc faciunt. Videtur per necessitatem posse excusari. Quo vero cum debeant vecturam bladorum dominis suis afferunt eam diebus feriandi vt reliquis debus profestis possint liberius consuetis et propriis vacare laboribus non sunt excusabiles in hoc nisi forte arta necessitas ad hoc eos compellat.”).

64 John of Erfurt, Die Summa Confessorum des Johannes von Erfurt, [The Summa of confessors of John of Erfurt] ed. Norbert Brieskorn (Frankfurt am Main: Peter D. Lang, I980), vol. 3, book 2.3.I, at I053 ("Item servi non peccant, si a dominis coguntur operari in festis, quando inducti iusto metu hoc faciunt, hoc Wil.”).

65 Astesanus of Asti, Summa de Casibus Conscientie [Summa on cases of conscience] (Cologne: Heinrich Quentell, I479), I.23.3, fol. $47 \mathrm{r}$ ("si faciant hoc iusto metu inducti videntur posse excusari.").

66 William of Pagula, Summa summarum, Durham Cathedral Library, MS C.II.I3, fol. 7or ("Illi autem qui a dominis suis compellantur operari in diebus festiuis si iusto metu inducti hoc faciunt propter necessitate excusantur. Qui vero dominis suis debeant victuram bladorum et eam asserunt diebus feriandis vt reliquis diebus possint liberius consuetis et propris laboribus vacare uero sunt excusabiles in hoc nisi forte arta necessitas ad hoc eos compellat."). The same statement is included in at least two other manuscripts of the Summa summarum. See British Library Royal MS Io D X, fol. 86v; British Library Harley MS 50I4, fol. 85 r.

67 Denis the Carthusian, Vices and Virtues, trans. Íde M. Ní Riain (Portland: Four Courts Press, 2009), Book 2.39, pp. 289 ("And those whose masters compel them to labour on feast days, and who obey out of genuine fear, do not, in my opinion, sin. Necessity excuses them.”).

68 Angelo Carletti, Summa Angelica de Casibus Conscientialibus [Summa angelica on cases of conscience] (Venice: Apud Iac. Sansouinum Venetum, I 569), s.v. "Ferie" \$I9, fol. 26Iv ("de rusticis quae compelluntur a dominis laborare, dic que si iusto metu faciunt est necessitas, qua excusat alias non. Idem dic de famulis filiis familias uxore, et huiusmodi."). 
Middle English treatise on the Decalogue composed around I405-IO, appears to have argued that servants were still bound to follow orders on holy days. His work appears to have relied mainly on the Summa confessorum by John of Freiburg. Dives and Pauper is written in the form of a dialogue between an ignorant rich man and a knowledgeable poor man. Dives asks whether servants who travail on Sunday by compulsion of their "souereynys" are excused.69 Pauper explains that they are excused if they principally work because of the "dred and obedience" that they owe their sovereign, so long as the type of work is lawful in itself. Pauper backs up his statement by paraphrasing I Samuel I 5:22, saying "God louyth mor obedience pan sacrifice." 70 He then adds a warning to sovereigns (masters) that the Third Commandment is bidden principally to them.

Some writers after the I 33 os explicitly stated that servants were not bound to obey their masters, using the phrase "non tenentur obedire nisi in licitis et honestis." There must have been some discussion about the ambiguities posed by the previous statements that servants did not sin on holy days when compelled to work by their masters. The Dominican friar and legist Bartholomew of San Concordio (I260-I347) included it in his Summa casibus conscientiae (ca. I338)-also known as Pisanella. He sought to update John of Freiburg's Summa confessorum. ${ }^{7 \mathrm{I}} \mathrm{He}$ is a bit more original with word choice, but the central idea remains the same: servants do not $\sin$ if they work under their master's orders. He departs from the standard explanation offered by William of Rennes, Vincent of Beauvais, John of Freiburg, and John of Erfurt by adding, "If they do this having been induced by just fear, they are considered to be excused because of necessity, otherwise they are not bound to obey unless in lawful and honest [works]." ${ }^{2}$ It seems that Bartholomew is trying to say that servants do not have to obey their masters on holy days unless necessity compels them. The same statement is quoted verbatim by Nicholas de Ausimo (d. 1453) in his supplement to the Pisanella. ${ }^{73}$ Baptista de Salis (late fifteenth century), relying heavily on Nicholas de Ausimo, also includes it in his casuistic manual, known both as the Summa baptistiniana and as the Summa rosella. 74 The legist Albericus de Rosate Bergomensis includes the same

69 Priscilla Heath Barnum, ed., Dives and Pauper, vol. I, part I, Early English Text Society 275 (London: Oxford University Press, 1976), 292-93 ("3if pei trauaylyn \& don her maystrys byddynge principaly for dred \& for obedience pat pey owyn to her souereyn $\&$ nout for couetyse ne for non opir euyl cause [and pe maner of trauayle be leful in itself], pan pey arn excusyd, for, as holy writ seith, God louyth mor obedience pan sacrifice. But war pe souereyn pat compellyth his seruant to trauaylyn in pe Sonday or ony grete feste withoutyn gret nede, for to pe souereynys is halwyng of pe halyday principaly bodyn. For withoutyn her wil her seruant ne her beste schal don comely no seruyle wark.”).

70 I Samuel I 5:22 ("And Samuel said: Doth the Lord desire holocausts and victims, and not rather that the voice of the Lord should be obeyed? For obedience is better than sacrifices: and to hearken rather than to offer the fat of rams.”).

7I Bartholomew was successful in disseminating the ideas found in the Summa confessorum. There are 608 extant manuscript copies of the Summa de casibus conscientiae but only I69 copies of the Summa confessorum. John A. Lorenc, "John of Freiburg and the Usury Prohibition in the Late Middle Ages: A Study in the Popularization of Medieval Canon Law" (PhD diss., University of Toronto, 2013), I27, 192-94. See also Michaud-Quantin, Sommes des casuistique, 60-62.

72 Bartholomew of San Concordio, Summa casibus conscientiae [Summa on cases of conscience], Newberry Library, MS 78 , fol. I33v ("Sed quid de illis qui compelluntur a dominis quia operentur in festis. Raymundo secundum Willelmum. Si iusto metu inducti hoc faciunt videntur propter necessitatem excusari alias non tenentur obedire nisi in licitis et honestis.").

73 Nicholas de Ausimo, Supplementum Summae Pisanellae [Supplement to the Summa Pisanella] (n.p., I473) s.v. "Ferie," unfoliated ("Si iusto metu inducti hoc faciunt videntur propter necessitem excusari alias non tenentur obedire nisi in licitis et honestis.").

74 Baptista de Salis, Summa Casuum Conscientiae [Summa of cases of conscience] (Nuremburg: Anton Koberger, I488), fol. I05r ("Quid de illis qui a dominis suis operari coguntur in festis: Raymundus.Secundum. 
statement in his Dictionarium Iuris tam Ciuilis, quam Canonici (after I350).75 Notably, Albericus de Rosate's definition cites John of Freiburg, even though the Summa confessorum does not state that servants are not bound to obey. It seems that by Albericus's day, the statement about servants not being bound to obey was an important part of the idea being presented. The phrases used by Bartholomew and Albericus differ from that used by John of Freiburg, perhaps indicating that Bartholomew and Albericus were not mindlessly copying what they found in the confessors' manuals but were absorbing the ideas and reformulating them into their own words. It appears that they were trying to clarify what they thought John of Freiburg had meant.

From Pisanella onward, confessors' manuals tended to place the discussion of masters and servants on holy days in its own rubricated section. Previously, the statement had occurred in the midst of a long chapter concerning a variety of works permitted because they were necessary. It seems that by placing the discussion in its own section, writers sought to draw attention to it. They did not, however, agree whether the next discussion (concerning those who owed carriage duties to their lords) was a logical part of the discussion. John of Freiburg did not place it in its own section, but John de Burgh did. By placing it in its own section, writers seem to have suggested that the idea could be applied to servants who labored for money, not just unfree villeins.

Like their peers on the Continent, English writers drew on confessors' manuals in explicitly stating that servants did not have to follow the orders of their masters on holy days. England was not insulated from the Continent in this regard. John de Burgh (fl. I370-I398) wrote a practical guide for priests called the Pupilla oculi, based on William of Pagula's Oculus sacerdotis. ${ }^{76}$ John de Burgh says that servants who work out of just fear are excused, but not those who work without compulsion, because they are not bound to obey their lords except in lawful and honest works. On holy days, only those works required by necessity are lawful. After excusing servants induced to work by just fear, John de Burgh declares that "otherwise [they are] not, because they are not bound to obey them [their lords] unless in lawful and honest [works]." 77 His statement differs from that of Albericus de Rosate on one important word: "because" (quia). ${ }^{78}$ Albericus de Rosate had said

Willelmum. Si iusto metu inducti hoc faciunt excusantur aliis tenentur non obedire nisi in licitis et honestis. Qui vero debent dominis suis vecturam bladorum et afferunt diebus feriandis: vt diebus alijs vacare proprijs laboribus liberius possint: non excusabiles: nisi forte ad hoc arta necessitas eos cogat.”).

75 Albericus de Rosate Bergomensis, Dictionarium Iuris tam Ciuilis, quam Canonici, s.v. "Feria vide supra” "QQuid de illis, qui compelluntur dominis suis, vt operentur diebus festiuis? dic si iusto metu faciunt, videntur necessitate excusari: alias non tenentur obedire, nisi in licitis \& honestis.no.in. sum.con.eo.ti.q.ix. Quid de illis, qui debent dominis vecturam bladorum, \& conducunt in die festo: dic quia non excusantur: nisi alia necessitas eos cogat. ea.q.ix.”).

76 Leonard Boyle dismissed de Bugh's work as derivative, but R. H. Helmholz has argued that the better organization of the Pupilla oculi makes it notable in its own right. It was also printed multiple times in the fifteenth and sixteenth centuries, whereas Pagula's Summa summarum was not. See Leonard E. Boyle, "The Oculus Sacerdotis of William of Pagula," Transactions of the Royal Historical Society, no. 5 (I955): 8I-1 Io, at 85; R. H. Helmholz, "John de Burgh ( $f$ I $1370-\mathrm{I} 398$ )," Ecclesiastical Law Journal I8, no. I (2016): 67-72, at 69-70. See also R. M. Ball, "The Education of the English Parish Clergy in the Later Middle Ages with Particular Reference to the Manuals of Instruction" (PhD diss., Cambridge University, I 977), 46-77.

77 John de Burgh, Pupilla Oculi [Apple of the eye] (London: Wolfgang Hopyl, I 5 IO), 9.6.K, fol. I 57 r ("Illi etiam que a dominis suis compelluntur operari in diebus festiuis si iusto metu inducti hoc faciunt: videntur propter necessitatem excusari: alias non quia non tenentur eis obedire nisi in licitis et honestis.”).

78 "Quia" does not seem to be a scribal error. It was also included in several manuscripts of the Pupilla oculi (every manuscript I have examined) and the edition printed at Paris in I 527: British Library, Harley 5442, fol. I83r; British Library, Harley 5435, fol. 343r; British Library, Royal 8 D I, fol. I80v; British Library, Royal 7 B X, fol. 209v; Corpus Christi College Cambridge, MS 2II, fol. I42v; Corpus Christi College Cambridge, MS 255 , fol. I9or-v; Pupilla Oculi (Paris: I 527), unfoliated. 
"otherwise, they are not bound to obey unless in lawful and honest [works]."79 John de Burgh's statement, though incorporating the phrase found in Albericus's Dictionarium, seems to have departed from his predecessor's meaning. Albericus de Rosate merely said servants were not bound to obey their masters' orders to work on holy days. He did not definitively say whether servants sinned if they followed orders from their masters that were not backed up by threats. Perhaps the implication is that they did sin; having a choice to follow orders may imply that they are solely responsible for actions and any resulting sin. Or maybe some or all of the blame lies with the masters for asking them to work. But without a clear statement, it is uncertain how blame is to be assigned. In contrast, John de Burgh explicitly refuses to excuse servants who work without just fear. For de Burgh, servants can be excused only when they fear the consequence of saying no. They have a duty to refuse their lord's commands on a holy day if they are not afraid of what their lord might do.

Some writers from the mid-fourteenth century onward argued that servants had an overriding imperative to disobey the commands of their temporal masters on holy days, just as their European counterparts did. Dives and Pauper seems to have been unusual in implying servants had to obey masters on holy days. One of the earliest writers to explicitly argue this point was the English Dominican friar John Bromyard (d. I352?) in his handbook for preachers. He supports his position by citing the Bible instead of confessors' manuals. ${ }^{\circ}$ Bromyard argues that servants do not have to obey orders to work on holy days. He encourages masters to realize that everyone is a servant to God on days ordained for the reverence of God. ${ }^{81}$ A servant on "the days of God are bound to the servitude of God... . Therefore, reason says, that because they are held in servitude ... by two lords for different days ... one of those lords does not have that servant ... for the day ... nor is the servant bound to obey him." ${ }^{82}$ Bromyard's comments were likely inspired by Matthew 6:24. ${ }^{83}$ Bromyard states that servants do not have to obey their masters with the phrase nec seruus tenetur ei obedire. It seems as if Bromyard modified the phrase "otherwise they are not bound to obey" (alias non tenentur obedire) to clarify his position on the matter. Bromyard argues a related point in his treatise Opus trivium, which discusses divine, canon, and civil law. ${ }^{84} \mathrm{He}$ applies legal theories about guilt to holy days. Masters who order their servants

79 Albericus de Rosate Bergomensis, Dictionarium Iuris tam Ciuilis, quam Canonici, s.v. "Feria vide supra," "QQuid de illis, qui compelluntur dominis suis, vt operentur diebus festiuis? dic si iusto metu faciunt, videntur necessitate excusari: alias non tenentur obedire, nisi in licitis \& honestis.”).

80 Even though he cited John of Freiburg twenty-two times in the Summa Praedicantium, he did not use him in his discussion on holy days. See Keith Walls, John Bromyard on Church and State: The Summa Predicantium and Early Fourteenth-Century England: A Dominican's Books and Guide for Preachers (Market Weighton: Clayton-Thorpe, 2007), 55.

8 I John Bromyard, Summa Praedicantium [Summa of preaching] (Venice: Apud Dominicum Nicolinum, I 586), vol. I, fol. 282r ("Ex primo cogitare deberent, quod sicut inferiors sunt eis subditi.").

82 John Bromyard, Summa Praedicantium, vol. I, fol. 282v ("Ex secundo puncto considerare debereut, quod persones subditorum plus Deo tenentur, quam eis, \& ita obligantur pro diebus Dei ad Dei seruitium. Ratio ergo dictat, quod qui tenentur in aliqua seruitute duobus dominis pro diuersis diebus, quod unus illorum dominorum non habet seruum illum a seruitute alterius domini pro die sibi debito retrahere, nec seruus tenetur ei obedire.”).

83 Matthew 6:24 ("No man can serve two masters. For either he will hate the one, and love the other: or he will sustain the one, and despise the other. You cannot serve God and mammon.”).

84 John Bromyard, Opus trivium validis auctoritatibus tam ex lege divina canonica civili refertissimum: cunctisque verbi dei declamatoribus perquam necessarium [Treaty of civil and canon law] (Lyons: Nicolai Wolff, I 500), s.v. "Festiuitates dei" ("Quante. maiori ratione et primum. quia si hoc verum est ille est in maiori periculo qui precepit seruis suis hoc facere et tamen talibus preceptis parendo non excusatur filius nec seruus. quia potius 
to kill others are guilty of murder, just as masters who force their servants to work on holy days are guilty of nonobservance. ${ }^{85}$

Fifteenth-century writers were even more explicit that servants were innocent if forced to work by their masters. The Franciscan Saint Bernardino of Siena ( $1380-\mathrm{I} 444$ ), citing William of Rennes, absolves servants from blame, placing all the guilt solely on masters. He includes city officials with masters as part of his discussion. He says, "However if they [masters] ordered it [servile work] without just cause . . . all the guilt belongs to the ones ordering, and not to the ones obeying." 86 He uses war as an example of a just cause. If a just cause exists, then both the ones ordering and the ones obeying are excusable. Saint Antoninus of Florence (I389-I459), a Dominican, also includes the discussion in his Summa Theologica. ${ }^{87} \mathrm{He}$ says that servants compelled by their lords to labor in their fields, carry wood ${ }^{88}$ or stones, make edifices, and dig pits may be excused because they might be damned in person or matters if they did not. Presumably, he is referring to beatings or fines. These threats, apparently justifiable fears, constitute necessity for the servants. The type of work does not constitute necessity, which is interpreted on an individual basis. None of the previous writers were clear whether necessity applied to the health and well-being of the servant. Their ambiguous answers could be interpreted as pertaining to collective threats, such as war or famine. Antoninus further remarks that it is "good they were not made to obey." His discussion takes the issue of necessity in a new direction.

In fifteenth-century England, socioeconomic developments may have had an effect on how writers interpreted the issue. The English canonist William Lyndwood (ca. I375-I446) cites John of Freiburg in his commentary on an ordinance from Henry Chichele, the archbishop of Canterbury (r. I4I4-I443), mandating the observance of the feast of Saint George the Martyr. ${ }^{89}$ Lyndwood reports that John of Freiburg believes just fear excused laborers for working

obedire patri quam magistro ciuitatis. ... Sic deus puniet illum qui plus obedit cuicumque quam sibi. qui dicit peribitur si non obedientes fueritis. Deut.viij. et istud periculum.").

85 John Bromyard, Opus trivium, s.v. "Festiuitates dei" "“si seruus sciente domino aliquem occiderit insolidum dominum obligat. Ipse enim dominus videtur occidisse. . . Maiori ratione dominus tenebitur si permitti serum vel subditum auferre vel farari tempus dei vel aliud peccatum contra deum facere.").

86 Bernardino of Siena, "Sermo X," in Opera Omnia, ed. Augstini Sépinski (Florence: Ex Typographia Collegeii S. Bonaventurae, I95 I) 3:178 ("Secundus casus est de iis qui compelluntur a dominis seu ab officialibus civitatum atque terrarium in solemnitatibus laborare. Tales, si iusto metu hoc facere compelluntur excusabiles sunt vel non tenentur parere, nisi in rebus licitis et honesties. Ceterum qui eis laborare praecipiunt, si id agunt cogente eos necessitate, scilicet guerrae vel quacumque alia causa iusta, tunc quidem excusabiles sunt praecipientes atque obedientes. $\mathrm{Si}$ autem sine iusta causa in praecipiente sed non sine iusto metu in obediente id fiat, tota culpa est praecipientis et non obedientis.”).

87 Antoninus of Florence, Summa Theologica, 4 vols. (Graz: Akademische Druck- U. Verlagsanstalt, I959), 2:986d ("Item qui compelluntur a dominis justo metu ad laborandum in diebus festivis in agris suis, vel deferrendum ligna, vel lapides, vel faciendum aedificia, vel foveas, \& huiusmodi, quae si non facerent, notabiliter damnificarentur in persona vel rebus; videntur posse excusari propter necessitatem. Melius tamen facerent non obedire, quando opus illud non est necessarium.”).

88 Likely a reference to Numbers I 5:32-36 ("And it came to pass, when the children of Israel were in the wilderness, and had found a man gathering sticks on the sabbath day, that they brought him to Moses and Aaron and the whole multitude. And they put him into prison, not knowing what they should do with him. And the Lord said to Moses: Let that man die, let all the multitude stone him without the camp. And when they had brought him out, they stoned him, and he died as the Lord had commanded.").

89 William Lyndwood, Provinciale, (seu Constitvtiones Anglice, [The Provinciale, (or Constitutions of England)] (Oxford: H. Hall Academiæ Typographus, I679), s.v. "Omni servili opera," I03 ("Putat etiam, quod justo metu dominorum laborantes in diebus festivis hujusmodi excusantur: non tamen putat eos excusari, qui aliqua vehere tenentur ad commodum aliorum, si vecturam hujusmodi faciant diebus festivis, ut liberius diebus profestis possint vacare necesitatibus propriis, nisi arcta necessitas sit in causa."). 
on festival days; however, they are not excused if they carry (vehere) for the profit of others. Lyndwood's understanding of John of Freiburg appears to differ from what the Summa confessorum actually says. Lyndwood does not explicitly make a connection between necessity and servants who worked on holy days; he simply notes that servants induced by just fear are excused. Additionally, servants are not excused if their master or employer profits from their endeavors, regardless of necessity or fear. He also does not mention whether lords are guilty of sin for making their servants work. Lyndwood's understanding seems to presuppose that servants have a duty to avoid working for a profit on holy days, even if they have just fears. He uses language that potentially portrays servants on holy days as free men. He says that on holy days they are like a free man (liberius) to be idle (vacare), unless dire necessity causes them to work.

Fifteenth-century interpretations of the English common law seem to depart from works influenced by canon law. The common law held that servants were always bound to obey their masters as long as they were in service, even on holy days. A I 443 case in the court of common pleas specified that servants were always in their master's service, even on holy days. The chief justice of the court, Richard Newton, reasoned that since the common law adjudges servants to be always in the lord's service, a master could coerce his servant to serve him at his will, whenever he pleased. Even when the servant went to church to serve God on the holy day, the common law still maintained that he was in service to his temporal lord..$^{\circ}$

\section{ECCLESIASTICAL COURTS AND COERCION}

The ecclesiastical courts cited masters for compelling their servants or dependents to work or miss church on holy days. They do not appear to have implemented a uniform policy regarding whether servants were to blame for being forced to work on holy days. The ambiguity of the confessors' manuals meant that the courts adopted different policies. The ecclesiastical court of Wisbech tended to cite both the master and servant. The servant was cited for working on a holy day, while the master was cited for compelling the servant to work. Even within the Wisbech court, however, there were contradictory cases when masters could have been cited but were not. The ecclesiastical court of Hartlebury seems to have preferred to cite masters rather than servants. The Salisbury visitation of I 394 cited both servants and masters. The London commissary court tended to cite just the master. Judges appear to have held different views about who was to blame, just as the authors of the confessors' manuals did.

Confessors' manuals used the terms master (dominus) and servant (servus) in their discussion concerning those who forced their subordinates to labor on holy days. Embedded in the discourse was the underlying principle that coercion in unequal relationships could influence culpability. Several courts seem to have applied this concept to other unequal relationships, especially those involving the head of the household-spousal and paternal relationships. Husbands were cited for making their wives work on holy days and fathers for making their children miss church. In

90 Thomas Hungerford Case ( 1443 ) Y. B. Mich. 22 Hen. 6, pl. 49, accessed through Legal History, the Year Books, https://www.bu.edu/phpbin/lawyearbooks/display.php?id=I8322 ("[The lord] can, when he pleases, command him to serve in his house, or in his business (besoignes), thus the law adjudges him always in the lord's service ... if one be retained by me in service, and not come to serve me, and another takes him and coerces him to serve him, I will have an action against him 'for taking my servant', because the law adjudges him always in my service, and I can coerce him to serve me when I want; and if my servant go to church on the Sabbath day to serve God, and another take him or beat him, I will have my action against him, and yet he was at this time in secular service to God and in His service, and not (following) my service, but the law adjudges him always in my service."). 
essence, the courts adopted a legal framework based upon coercion in unequal relationships instead of simply focusing on the master-servant dynamic. This framework was probably well suited to practice in the courts. The real world was messy. Judges would come across men who forced their wives and children to break holy days, and they needed guiding principles to help them judge such cases. To shed more light on how the courts dealt with cases involving coercion, this article includes cases where husbands or fathers prevented family members from observing holy days.

Roger de Marlowe, the priest of Harwell (r. I292-I3 IO), believed that ecclesiastical courts should punish servants who obeyed orders to work on holy days, as well as masters who ordered their servants to work on holy days. Marlowe asked the archdeacon of Berkshire to act against some people who worked on a Sunday. ${ }^{9 \mathrm{I}}$ Marlowe was upset that the harvester in Harwell ordered the tenants of the manor to cart hay on a Sunday. He sent the chaplain of the parish to prevent them from working, but they refused to heed his repeated threats. The harvester refused to allow others to stop working. Marlowe summoned the offenders separately to appear before the archdeacon's court. He encouraged the archdeacon to punish the harvester for "habitually working on holy days and encouraging others to do the same." Apparently, Marlowe believed that encouraging others to work on holy days was an actionable offense. Additionally, he seems to have believed that servants should disobey their masters' orders to work on holy days. Their master, the harvester, made it clear that he would not allow them to stop working-Marlowe even noted that the harvester was a powerful man. The tenants might face serious repercussions for disobeying him. Regardless of the repercussions, Marlowe clearly believed that the tenants were obligated to refrain from work. He asked the archdeacon to punish them in order to deter others from following their example.

Marlowe's belief that it was illicit to force others to work on holy days was realized in Salisbury. In I394 there was a "purge" against Salisbury tradesmen involved in the cloth industry by an ecclesiastical court, which cited both masters and servants. It cited servants for working on holy days and masters for compelling their servants to work. Thomas the servant of George Joice, John the servant of Nicholas Joyce, James the servant of Edward Passewell, and Hugh the servant of Roger Sherman were cited for working on holy days. Walter Cokke, John Tukke, Edward Passewell, John Bayly, Robert Colyn, Edward att Nasse, John Tuddeworth, and John Kendale were cited for working on holy days and compelling their servants to work. ${ }^{22}$ It appears that the court may have differentiated between servants who worked from their own volition and those

9I Rosalind T. Hill, “A Berkshire Letter-Book,” Berkshire Archaeological Journal, no. 4I (I937): 9-32, at 23 [Hill edits, translates, and discusses Roger de Marlowe's letter-book] ("It is my duty to tell your discretion that last Sunday ... the Bishop of Winchester's harvester in Harwell, summoned or caused to be summoned all the tenants of the said Bishop in the said vill, ordering them to come to the park of the said Bishop immediately after nine o'clock to cart hay ... this seemed to me unbearable, so I immediately sent Sir Thomas my colleague, chaplain of the parish, to prevent such work upon that day, but they would not listen to him or desist from their work. So I warned them three or four times to stop and afterwards threatened them with excommunication if they went on, but I labored in vain, for the said $\mathrm{H}$. . . answered me mockingly that he was going to cart the hay whether I liked it or not, nor would he cease work, or permit others to cease, for my threats or warnings. . . . I therefore, being somewhat disturbed ... had them summoned separately to appear before you in your chapter ... to hear and receive the sentence which your discretion should declare according to justice. Wherefore, I beg your discretion to give them a suitable sentence, punishing them so that others may not be tempted by the lightness of their sentence to follow their example, and let the harvester receive punishment for habitually working on holy days and encouraging others to do the same. He is a powerful man.”).

92 T. C. B. Timmins, ed., The Register of John Waltham: Bishop of Salisbury 1388-I395, Canterbury and York Society 80 (Woodbridge: Boydell Press, I994), 2I2-I3. 
who were coerced to work. George Joice and Roger Sherman were not cited, even though their servants were. Regardless, the records indicate that the Salisbury visitation of I 394 cited masters for compelling their servants to work on holy days. The court seems to have punished both master and servant.

John Bromyard had declared that when masters compelled their servants to work on holy days, both parties were guilty of nonobservance. Thus, masters had some degree of liability. The Salisbury court rejected this view, instead adopting the view that masters were not accessories to their servants' crime of nonobservance. By prosecuting both servants for working on holy days and masters for compelling their servants to work, the Salisbury court effectively declared that two crimes were committed when servants followed orders to work on holy days. The servants were completely and solely responsible for their sin. Masters were guilty only of compelling their servants to work on the holy day, which was ultimately different than being an accessory to nonobservance.

The Salisbury court also prosecuted powerful men who prevented people from attending church. The I39I visitation by Bishop Waltham resulted in the citation of John Prat of Porton for preventing the residents of Porton and Gomeldon from attending church in Idmiston; John Prat was probably related to Thomas Prat, the lord of Porton manor in I $349 .{ }^{93}$ By the late fourteenth century, the courts cited masters not only for forcing their servants to work but also for preventing others from attending church.

A case from Haynton in Lincolnshire suggests that its ecclesiastical court considered whether servants worked with the consent of their masters on holy days. In I 339, John of Gayton was charged with carrying grain cum duabus carectis (with two carts) on the feast of the Assumption of Mary. 94 The court specifically noted that he did it "contrary to the license of his lord." This was important because confessors' manuals specifically noted that serfs who owed their lord grain-carriage boon works were not permitted to work on holy days (unless necessity compelled). 95 In effect, the declaration that Gayton labored without the consent of the lord amounted to an eschewal of liability on the part of the lord. Whether a serf worked with or without the consent of the lord seems to have mattered to the court; the answer determined liability.

The Hartlebury court appears to have been inconsistent in citing masters and servants. In I4I 3 , it cited both William Stone and his servant Thomas for carting hay on the feast of Saint Anne. At the same session, the court cited John atte Thorne, but not his workers, for binding barley with his workers on Sunday. ${ }^{6}$ William Stone and John atte Thorne probably compelled or at least

93 Timmins, Register of John Waltham, I 59-60 ("John Prat of Porton prevents inhabitants of Porton and Gormeldon [from] going to Idmiston church then [on the four greater festivals] and on other days, as they wish and ought to go.").

94 L. R. Poos, ed., Lower Ecclesiastical Jurisdiction in Late-Medieval England: The Courts of the Dean and Chapter of Lincoln, 1336-1349, and the Deanery of Wisbech, I458-1484, Records of Social and Economic History, n.s., 32 (New York: British Academy, 200I), 99 ("Johannes de Gayton notatur quod die assumptionis beate Marie proximo preterito preter licenciam domini sui cariavit bladum cum duabus carectis et vicario suo grave fecit insultum, eo quod idem vicarious eidem Johanni monuit quod ab huiusmodi cariatione et opere desisteret. Comparuit et fatebatur et habet pro penitencia sex fustigationes circa ecclesiam parochialem et vj circa forum. Et habet diem erga vicarium ad diem ut supra.").

95 John of Freiburg, Summa Confessorum I.I 2.9, fol. 34r.

96 Robert N. Swanson and David Guyatt, eds., "The Visitation Book of Hartlebury, I40I-I 598," in Noble Household Management and Spiritual Discipline in Fifteenth-Century Worcestershire: A Household Account of Edward, Duke of York at Hanley Castle, I409-IO, ed. James P. Toomey, Robert N. Swanson, and David Guyatt, Worcestershire Historical Society, n.s., 24 (Bristol: Worcestershire Historical Society, 20I3), I2I-282, at 173 . 
encouraged their servants to work on holy days since they were caught working with them. However, the court charged them only with working on a holy day, not with compelling their servants to work. The issue is further complicated by a case several decades later. In I453, Thomas Holmer was cited for preventing his adult sons from attending church; 97 they do not appear to have been cited. The I 453 case clearly considered compelling others to break the law to be an illegal and a prosecutable offense, whereas neither of the $\mathrm{I}_{4} \mathrm{I} 3$ cases did. As in atte Thorne's case, the court considered the coerced parties innocent. Overall, the Hartlebury court appears to have been inconsistent in how it dealt with masters who encouraged their subordinates to work or miss church on holy days.

The Wisbech court tended to cite both servant and master in cases of nonobservance. The servant was cited for working, while the master was cited for encouraging the servant to labor on the holy day. The court seems to have been careful about the language it used. William Mannyng of Emneth was charged with carrying peat on the feast of Saint Ætheldrede (June 23). ${ }^{8}$ At the same session of the court, John Awsten was cited for causing his servant, one William Mannyng, to labor. ${ }^{99}$ The court also extended its reach to familial relationships. It cited John Reynold of Leverington for soliciting his son Robert to tear down a house on the feast of the Exaltation of the Cross, before citing Robert for nonobservance. ${ }^{100}$ It cited Thomas Nicholasson for failing to attend church and for causing and compelling his wife to absent herself from mass. ${ }^{\text {IOI }}$ His wife does not seem to have been directly cited for missing church, but the records indicate that she appeared with her husband before the court, and that they purged themselves. The fact that she purged herself suggests that she may have been held responsible for missing church.

The London commissary court tended to cite just the master. It appears that the court believed that servants had an overriding duty to obey the commands of the master, otherwise they would have been responsible for working on holy days. The court seems to have agreed with William of Rennes. Randulphus Carpynter was cited for working with all his servants and disregarding

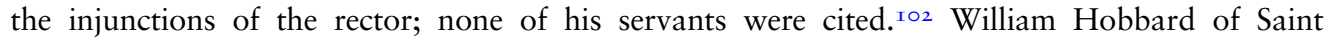
Alban's Woodstreet was cited for making certain men thresh hay on the feast of the Holy Trinity. ${ }^{103}$ The court also cited mistresses of the household. Agnes Buckaley was cited for violating the Sabbath by engaging in secular occupations with her famulis on the feast of Saint Martin and

97 Swanson and Guyatt, "The Visitation Book of Hartlebury," I73 ("Thomas Holmer . . has two sons of full age whom he prevents from coming to their parish church on feast days, and in no way instructs them in their catholic faith.”).

98 Poos, Lower Ecclesiastical Jurisdiction, 403 ("Willelmus Mannyng non servat sabbata vehendo terriscidias, videlicet turvys, in festo Sancte Etheldrede ultimo preterito. Suspensus ut supra.”).

99 Poos, 403 ("Joannes Awsten' causabat servientem suum Willelmum Mannyng laborare ut supra. Comparuit xxij ${ }^{\text {do }}$ die Novembris.").

Io० Poos, 4I 8 ("Idem solicitavit filium suum Robertum ad consimile peragendum dicto die. ... Idem Robertus taliter delinquit ut pater eius supra notatur.”).

IOI Poos, 286 ("Thomas filius Johannis Nicholasson absentat se omni die festive ab ecclesia sua tempore divinorum. Idem causat et compellat uxorem suam similiter absentare se a divinis. Comparuerunt pro isto articulo iiij ${ }^{\text {to }}$ die Novembris et negaverunt articulum et legitime se purgaverunt.”).

IO2 London Commissary Court Book, I483-I488, London Metropolitan Archives, DL/C/B/043/MSo9064:002, fol. 22V ("Randulphus Carpynter operatus est cum omnibus suis seruis in parochia Sancti Benedicti iuxa Powliswarf non obstantur prohibicionem rectoris.”).

I03 London Commissary Court Book, I475-I477, I480-I482, London Metropolitan Archives, DL/C/B/O 43/ MSo9064:003, fol. I3 8 r ("Williamis Hobbard fecit certes homines in festo Trinitatis defalcare fenum iuxta Walloke Bermo."). 
the Ascension of the Lord. ${ }^{104}$ William Steward's wife was also cited for working with her servants. ${ }^{105}$ The court also prosecuted masters who kept their dependents from attending church. The court cited Godfrey Sperynth and Paul Godfrey for not hearing mass in their parish church with their respective households. ${ }^{106}$

The Canterbury ecclesiastical court prosecuted masters. Clement Rolf was cited for causing his servant to labor on the feast of Saint Edward. ${ }^{107}$ Richard Arthe of Charring was cited on the feast of Saint Matthew for collecting seeds with his servant the whole day. ${ }^{\text {I08 }}$ John English of Saint Dunstan's parish in Canterbury was cited in I 500 for selling his merchandise "in one place and his servants in other places" - his servants were not cited. ${ }^{\circ 09}$ Alicia Marten of Saint Margaret in Canterbury was cited for not honoring the Sabbath one Sunday in I499. Instead of appearing before the court at the appointed date, her husband appeared in her place. He admitted that he had forced his wife to sell goods in the marketplace. The court seems to have accepted his confession and absolved Alicia. ${ }^{\text {I }}$ These cases were not very common, though. In fact, it seems that London's commissary court dealt with a larger proportion than Canterbury's court.

The Lichfield court appears to have at least prosecuted the heads of households for forcing dependents to work on holy days. It cited John Holmon for treating his wife badly, denying her food and rest from work on holy days. ${ }^{\text {II }}$

The English ecclesiastical courts do not appear to have been alone in prosecuting people for compelling others to labor on holy days. The ecclesiastical court of Carpentras, in southern France, pursued two coercion cases in I487. Jacomo Regis of Villas was prosecuted for ordering two servants to work on the feast of Saint Mark, while Johan Grimaud was held responsible when his son sold merchandise on the feast of All Saints. ${ }^{\text {I }}{ }^{2}$ The Tournai ecclesiastical court prosecuted Johannes van den Bulcke in ${ }_{5} 528$ for causing his servants to work on the feast of

I04 London Commissary Court Book, I483-I488, London Metropolitan Archives, DL/C/B/o43/MSo9064:002, fol. $23 \operatorname{Ir}$ ("Agnes Buckaley violator sabbatorum quia occupauit se una cum famulis suis in secularibus occupationibus videlicet in diebus sancti Martin . . . et die Ascencionis domini post vesperas et in diversis alijs diebus festiuis.”).

I05 London Commissary Court Book, I483-I488, London Metropolitan Archives, DL/C/B/043/MSo9064:002, fol. 79r ("Uxor Williami Steward similiter operata est cum suis.").

Io6 London Commissary Court Book, I475-77, I480-I482, London Metropolitan Archives, DL/C/B/O43/ MSo9064:003, fol. I 84r ("Galfridus Sperynth cum familia non audit diuina in ecclesia parochiali . . Paulus Godfrey cum familia non accedunt ad ecclesiam parochiam.”).

107 Canterbury Consistory Court Act Book for Hythe, Romney and Dover Sessions, I462-I468, Kent History and Library Centre, Dcb/J/X/8.3, fol. I8 Iv ("Clemenis Rolf de Troothrah notatur quia festo Sancti Edwardi ultima laborauit cum suo lewelyn per totum diem et causauit servum secum laborare eadem die.”).

I08 Canterbury Archdeaconry Court Act Book, I468-I474, Kent History and Library Centre, Dcb/J/Y/I.II, fol. 205v ("Ricardus Arthe de Charryng . . . in festo sancti Matthei vltima pro totam diem cum famula sua collegit seminam . . . videlicet acorum abstinendo se a diuine.").

I09 Canterbury Archdeaconry Court Act Book, I487-I 504, Kent History and Library Centre, PRC $3 / 1$, fol. I36r ("Johannis English de parochia sancti dunstani Cantuariensis notatur quia non seruat sabbatum sed quia ipsement in vno loco et seruientes sui in alijs locis omne die feriato solent publice tenere forum.”).

I Io Canterbury Archdeaconry Court Act Book, I487-1504, Kent History and Library Centre, PRC $3 /$ I, fol. I 3 or ("Alicia Marten de parochia sancte Margarete Cantuariensis notatur quia non colit sabbatum et praesertim die dominice proxime ante festum Michaelis proxime preterite comparuit sponsus eius et fatabatur se mandasse uxor eius ad vendendum merces in paro foro et quia mulier non comparuit sero.”).

II I Ann J. Kettle, "City and Close: Lichfield in the Century before the Reformation," in The Church in Pre-Reformation Society: Essays in Honour of F. R. H. Du Boulay, ed. Caroline M. Barron and Christopher Harper-Bill (Woodbridge: Boydell Press, I985), I 58-69, at I66.

II 2 Elizabeth L. Hardman, Conflicts, Confessions, and Contracts: Diocesan Justice in Late Fifteenth-Century Carpentras (Boston: Brill, 2016), I28. 
Corpus Christi. ${ }^{113}$ England was part of a much larger tradition in Western Europe that held masters responsible for the actions of their servants on holy days.

In the thirteenth century, when William of Rennes briefly discussed lords who compelled their servants to labor on holy days, he likely had in mind serfs who were compelled by their lords to perform boon works on holy days. The economy was still based on feudal obligations. By the fifteenth century, the economy had changed. Instead of providing labor services for their lands, many servants were more akin to employees. They received wages for their labors. Fifteenth-century courts were forced to deal with people who worked for wages on holy days. This presented a challenge to the confessors' manuals. Was it possible for servants who accepted wages for working on holy days to be coerced? Were they still considered servants? The ecclesiastical courts seem to have taken wage labor into consideration. The Wisbech court seems to have occasionally noted when there was wage labor on holy days. It cited Thomas Wrag of Whittlesey for driving steers of other men during the time of the divine and receiving six pence; ${ }^{\mathrm{II} 4}$ the court did not cite his employers. The London commissary court seems to have made the same distinction. Hugo Pareser was cited for working his hay on the feast of Saint Paul. He denied the allegations, explaining that the workers he hired to work the hay had done it on the holy day without his knowledge. This was, apparently, an acceptable argument, because the judge dismissed the charges. ${ }^{115}$ The court seems to have considered wage-laborers to be their own masters and, therefore, responsible if they worked on holy days.

\section{CONCLUSION}

Overall, divergent opinions could have an effect on the practice of medieval ecclesiastical courts. The medieval English ecclesiastical courts were willing to prosecute masters who forced their subordinates to work on holy days. They pursued different policies regarding how to assign blame. This was likely because the confessors' manuals were ambiguous. Masters clearly were to blame if they coerced servants. Could servants be held legally responsible if they were coerced? The uncertainty of this question was reflected in the practices of the courts. The Wisbech court seems to have thought so. It prosecuted masters specifically because they coerced their servants to work on holy days. Servants were apparently prosecuted because they could have refused the demands of their masters. Other courts disagreed. Both the Hartlebury courts and the London commissary court prosecuted only masters, implying that servants could not disregard their masters' orders.

I 3 Monique Vleeschouwers-van Melkebeek, ed., Compotus sigilliferi curie Tornacensis (I483-I53 I) Le tribunal de l'officialité de Tournai et les comptes du scelleur Introduction, édition et traduction française [Account of the sealer of the court of Tournai (I483-I 53I) The Court of the Official of Tournai and the accounts of the sealer, introduction, edition, and French translation] (Tournai: Art et Histoire Instruments de Travail, 20I6), I:586 ("Johannes vanden Bulcke quia die festi Sacramenti ultimo fecit vel fieri procuravit per suos famulos opus servile festum predictum.”).

I 4 Poos, Lower Ecclesiastical Jurisdiction, 536 ("Thomas Wrag die Dominico ultimo abegit buculos alterius viri tempore divinorum et ideo receipt vj d.").

I 5 London Commissary Court Book, I483-I488, London Metropolitan Archives, DL/C/B/O43/MSo9064:002, I I6r ("Hugo Pareser operabatur circa fenum in die sancti Pauli vir comparuit primo die Julij comparuit negat articulum sed dicit quia conduxit alios viros ad faciendum fenum suum et ipsi eo inscio operabantur hoc super quo in die martis proxima purgare se se 4 illo die dimittitur."). 
Dissension regarding whether servants had to obey their temporal lords on holy days lasted into the early modern era. ${ }^{\text {I } 16}$ Richard Byfield (ca. I 598-I 664) and Edward Brerewood (ca. I 565-I6I3) became embroiled in a dispute over whether a servant had the prerogative to disobey the orders of the master to work on a Sunday. ${ }^{117}$ Richard Byfield argued that the Third Commandment was given as much to servants as to their masters, thereby allowing servants to refuse orders to work on Sunday, while Brerewood argued that the commandment applied only to masters, and thus the only duty of servants was to follow the order of their masters. ${ }^{\text {I } 8}$ This dispute revolved around the issue of whether servants were obligated to disobey their temporal lord in obedience of their heavenly lord, and both authors heavily drew upon medieval thought about holy days to construct their arguments. The argument expounded by Byfield blatantly affirmed that the right to holy days existed for all, as he said of servants: "As thy servant, he is not thine in thy workes or servile workes that day, but the Lords freeman ... they are not void of liberty to refuse such workes on that day." II Brerewood argued that because servants had a duty to obey the orders of their masters even on holy days, bad masters who ordered their servants to work on holy days were solely guilty of sin.

Ecclesiastical courts continued to prosecute masters for making their laborers work on holy days in Tudor and Stuart England. Courts in Yorkshire, Oxfordshire, Somerset, and Norfolk prosecuted masters for making servants work on holy days. ${ }^{20}$ In I 594, William Drew of Newton in the diocese of Ely was forced to beg the forgiveness of God for making his servant "to carrie a sheeperacke to the pasture on the Sabboth daie." ${ }_{\text {I2I }}$ Thus, the issue survived well past the end of the Middle Ages.

I 6 Dissension was not limited only to England. In Reformation Scotland, the Aberdeen courts ruled in I 562 that servants were to come to church on Sunday "if their masters give them leave." But the Scoonie court session fined both master and servant even if the master ordered the servant to work instead of attend church. The Scoonie court's policy became widespread after the 1560 . See Margo Todd, The Culture of Protestantism in Early Modern Scotland (New Haven: Yale University Press, 2002), 36.

I 7 Christopher Hill, Society and Puritanism in Pre-Revolutionary England (New York: Schocken, I964), I76-82.

I 8 Richard Byfield, The Doctrine of the Sabbath Vindicated (London: Felix Kyngston, I63I).

I 9 Edward Brerewood, A Learned Treatise of the Sabaoth (Oxford: Iohn Lichfield, I636), 6, 42.

I 20 In I 566 Gavin Lemyng was cited for causing "certen laborers to mowe his barley . . . upon the Sabothe daie in harvest laste." In $\mathrm{I}_{6} \mathrm{I}_{3}$ a resident of Cotgrave was cited for "suffering his servant to threshe." R. F. B. Hodgkinson, ed., "Extracts from the Act Books of the Archdeacon of Nottingham," Transactions of the Thoroton Society of Nottinghamshire, no. 30 (1926): I I-57, at I2-I4. In I584, Richard Dunte, the warden of Henlie, was brought before the archdeacon for "settinge men on worke upon his howse on St. Peter's daye." E. R. Brinkworth, ed., The Archdeacon's Court: Liber Actorum, I584, The Oxfordshire Record Society 23 (Oxford: Bergess \& Son, I942), 54. In I 592, Walter Jobson of Pocklington, Yorkshire, was cited because his "tailor servantes wrought vpon Sondaie in the service tyme." T. M. Fallow, ed., "Some Elizabethan Visitations of the Churches Belonging to the Peculiar of the Dean of York," The Yorkshire Archooological Journal I 8 (1905): I96-232, at 224. In I 594, six individuals in Somerset were each fined for making their "folks" work upon holy days. Derek Shorrocks, ed., Bishop Still's Visitation 1594 and the 'Smale Book' of the Clerk of the Peace for Somerset 1593-4, Somerset Record Society 84 (Bristol: J. W. Arrowsmith, I998), I 2 I-23. In I593, John Parnell was charged with forcing his servant to work on holy days. Records of the Archdeaconry of Norwich [ANW], I455-I975, ANW 2 Visitation Act Books, I 566-I809, Norfolk Record Office; [ANW/2/3 I, fol. I 7v] ("James Parnell [is] no[ted] for setting his primus comonly to K[?] and work on his holy dais."). In Yorkshire, one Christian Gill, was cited in 1633 for "causeing all the Towne of Mounckton, upon St. Luke's day, when the people should have bene at prayers, to goe to drive the Moore to bring in his profitt.-He said it was the custom." Robert H. Skaife, ed., "Extracts from Visitation Books at York," Yorkshire Archceological Journal, no. I 5 (I900), 224-43, at 234.

I2I Hubert Hall, ed., "Some Elizabethan Penances in the Diocese of Ely," Transactions of the Royal Historical Society 3, no. I (1907): 263-77, at 266-67. 